Y/TS-1780

Y-12

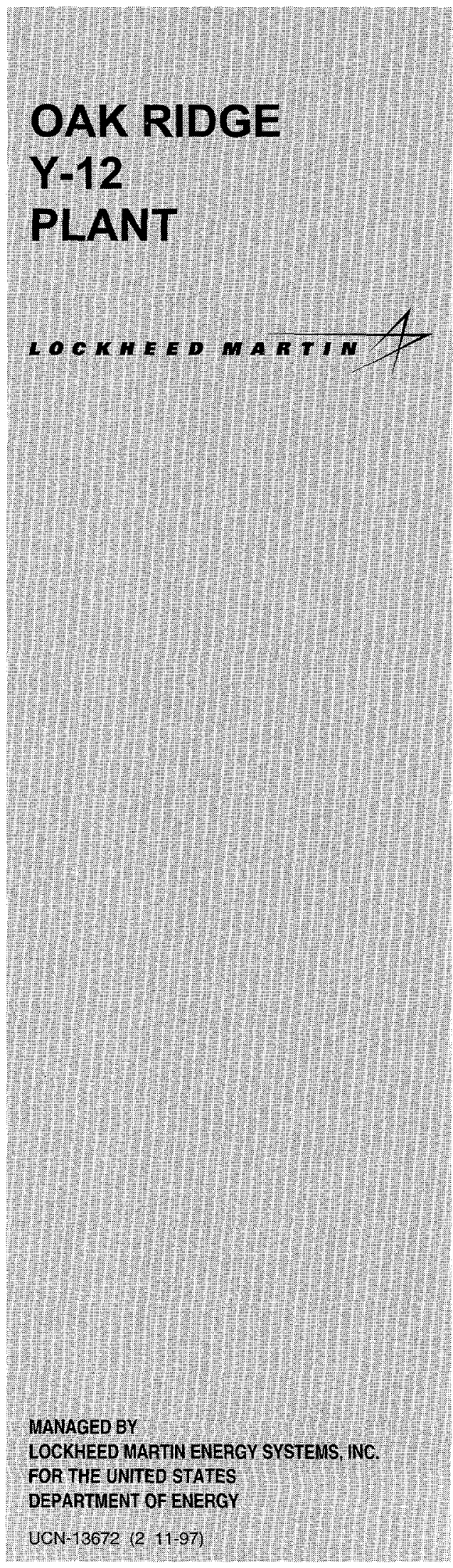

EMERGENCY PLANNING AND COMMUNITY

RIGHT-TO-KNOW ACT

SECTION 312 TIER TWO REPORT FORMS

\section{R. A. Evans}

Environmental Compliance Department

Environment, Safety, Health and Quality Organization

February 2000

\author{
Prepared by the \\ Oak Ridge Y-12 Plant \\ Oak Ridge, Tennessee 37831 \\ managed by \\ Lockheed Martin Energy Systems, Inc. \\ for the U.S. Department of Energy \\ under Contract DE-AC05-84OR21400
}




\section{DISCLAIMER}

This report was prepared as an account of work sponsored by an agency of the United States Government. Neither the United States Government nor any agency thereof, nor any of their employees, makes any warranty, express or implied, or assumes any legal liability or responsibility for the accuracy, completeness, or usefulness of any information, apparatus, product, or pracess disclosed, or represents that its use would not infringe privately owned rights. Reference herein to any specific commercial product, process, or service by trade name, trademark, manufacturer, or otherwise, does not necessarily constitute or imply its endorsement, recommendation, or favoring by the United States Government or any agency thereof. The views and opinions of authors expressed herein do not necessarily state or reflect those of the United States Government ar any agency thereof. 


\section{DISCLAIMER}

Portions of this document may be illegible in electronic image products. Images are produced from the best available original document. 
Y/TS-1780

\title{
EMERGENCY PLANNING AND COMMUNITY \\ RIGHT-TO-KNOW ACT \\ SECTION 312 TIER TWO REPORT FORMS
}

\author{
R. A. Evans \\ Environmental Compliance Department \\ Environment, Safety, Health and Quality Organization
}

February 2000

Prepared by the Oak Ridge Y-12 Plant

Oak Ridge, Tennessee 37831 managed by

Lockheed Martin Energy Systems, Inc.

for the U.S. Department of Energy

under Contract DE-AC05-84OR21400 


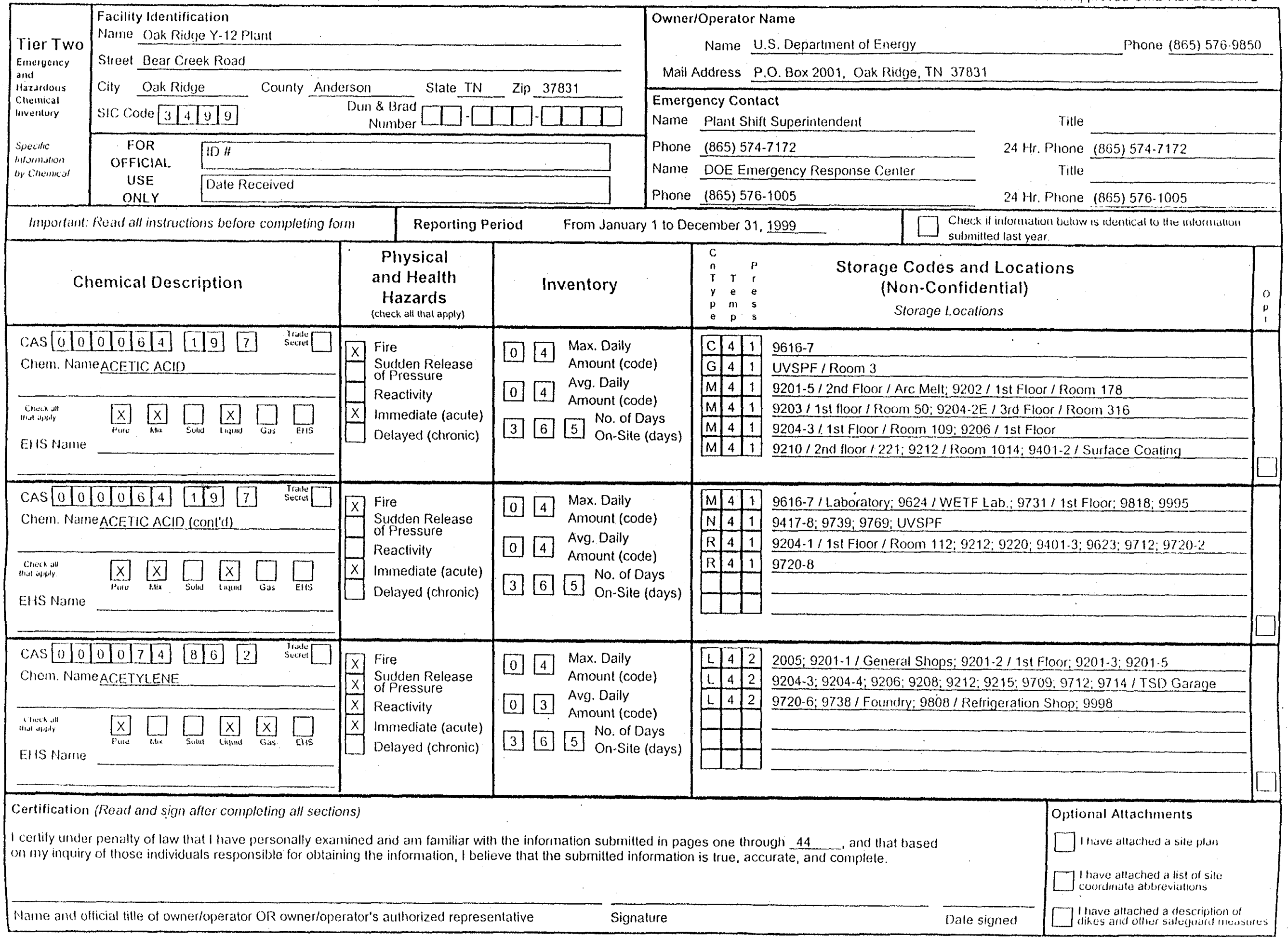




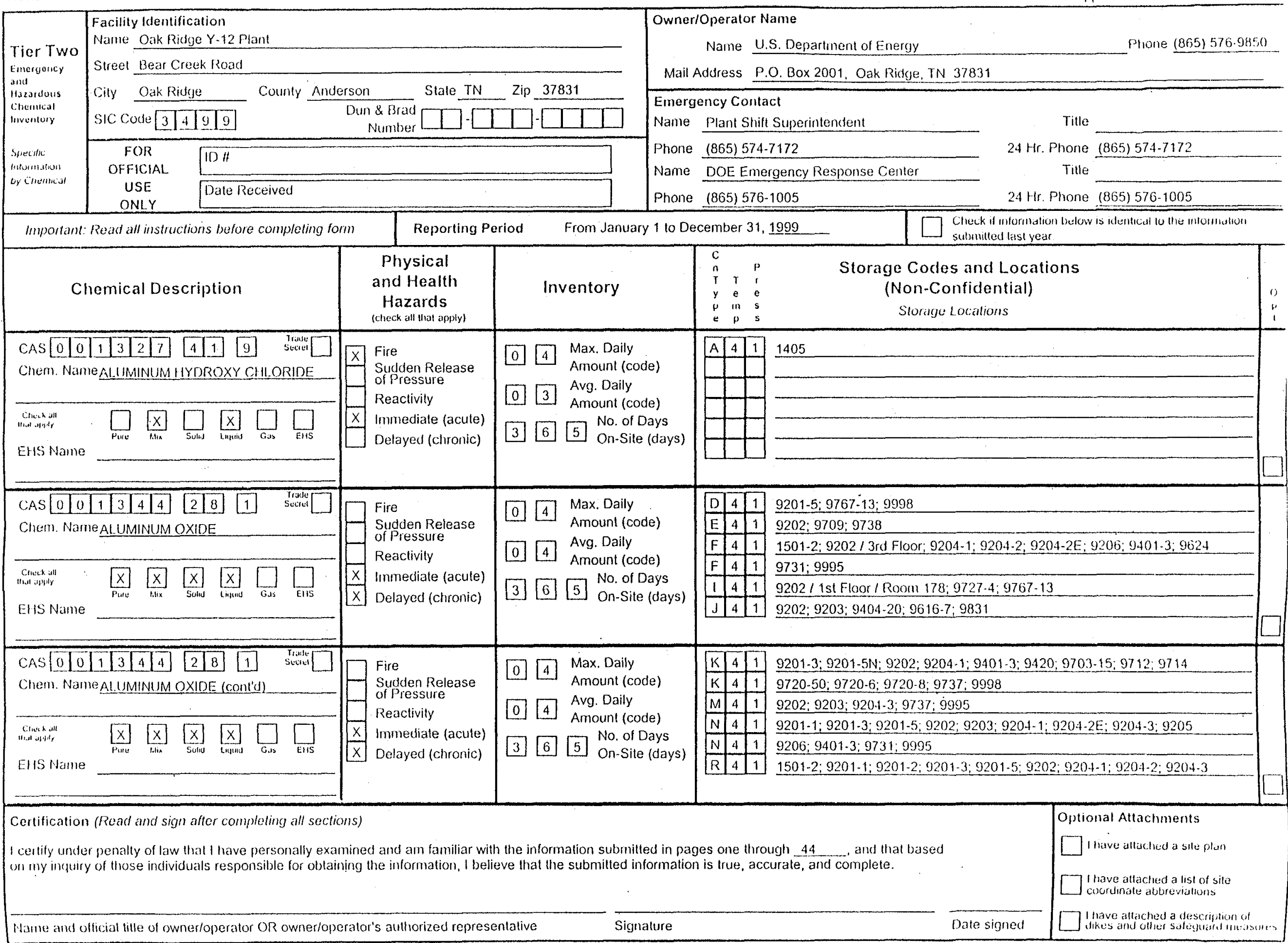




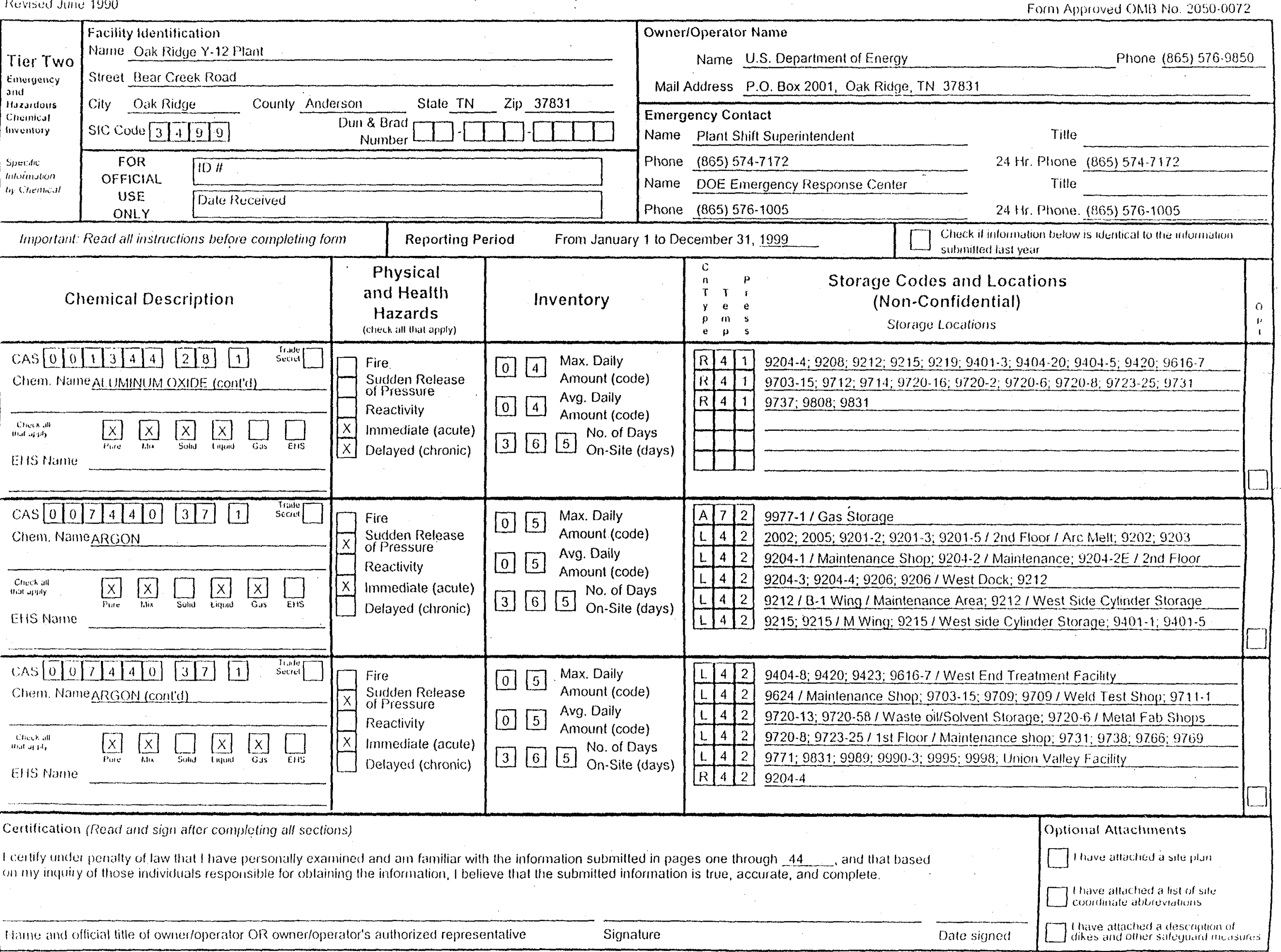




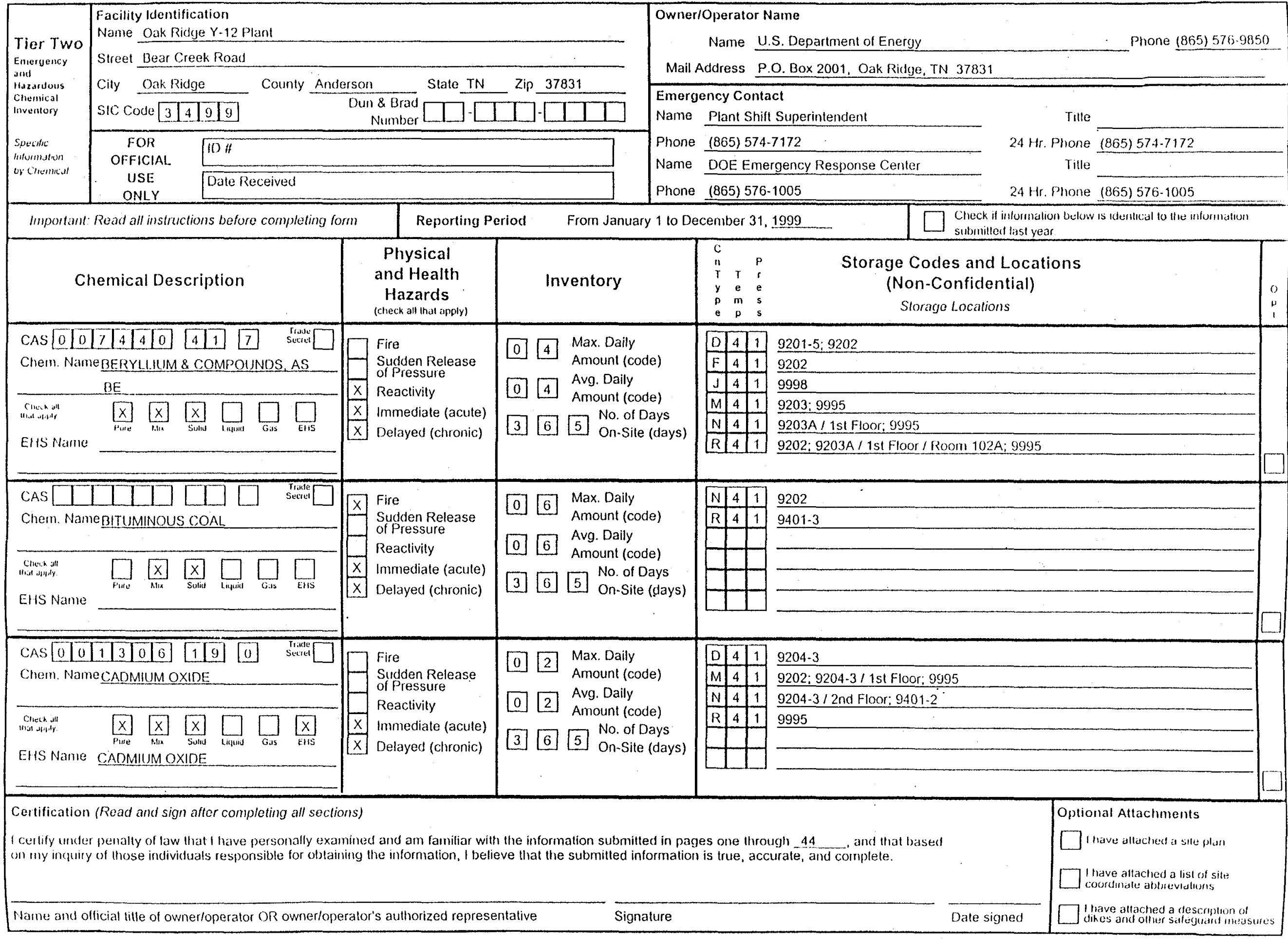




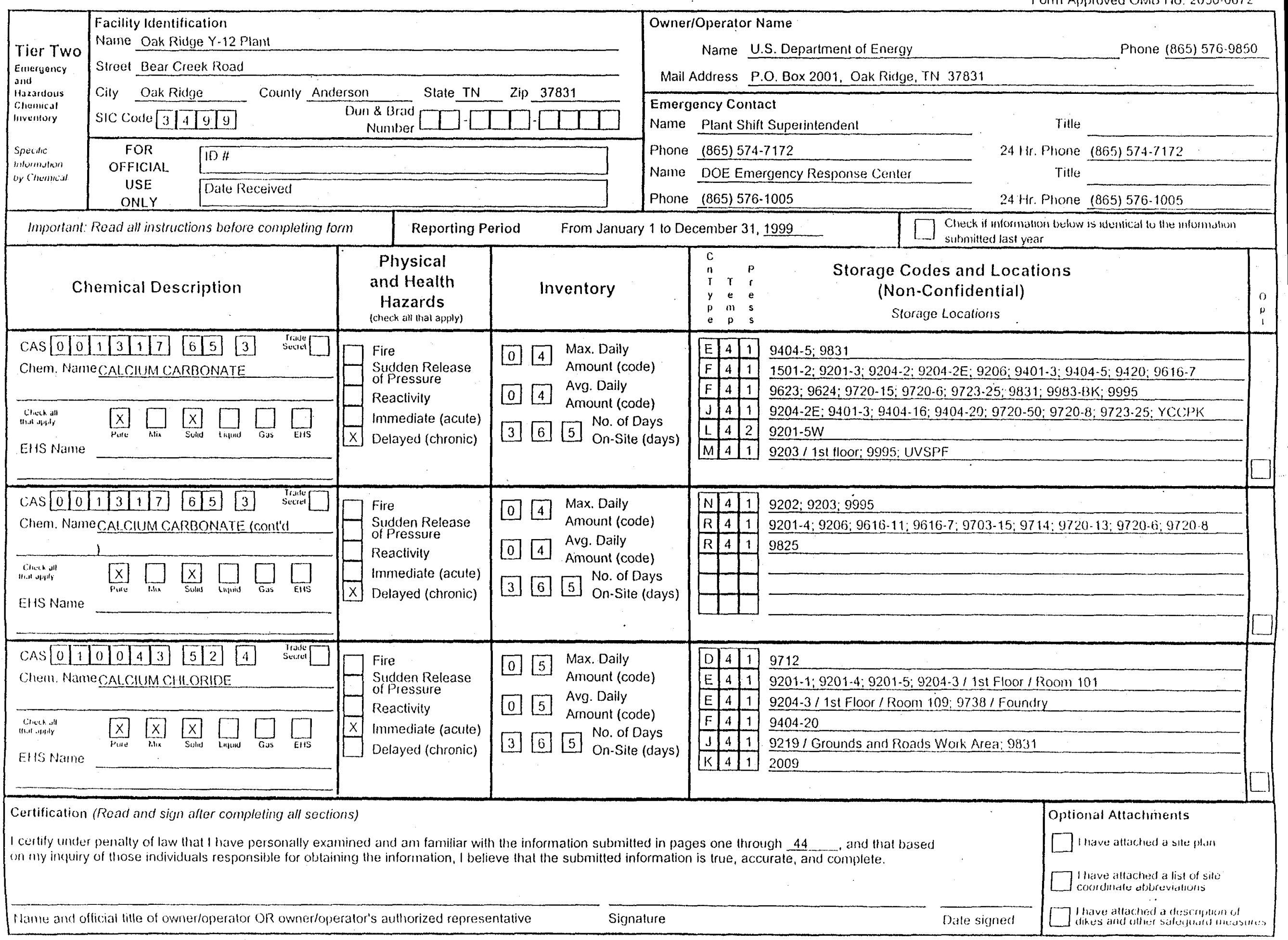




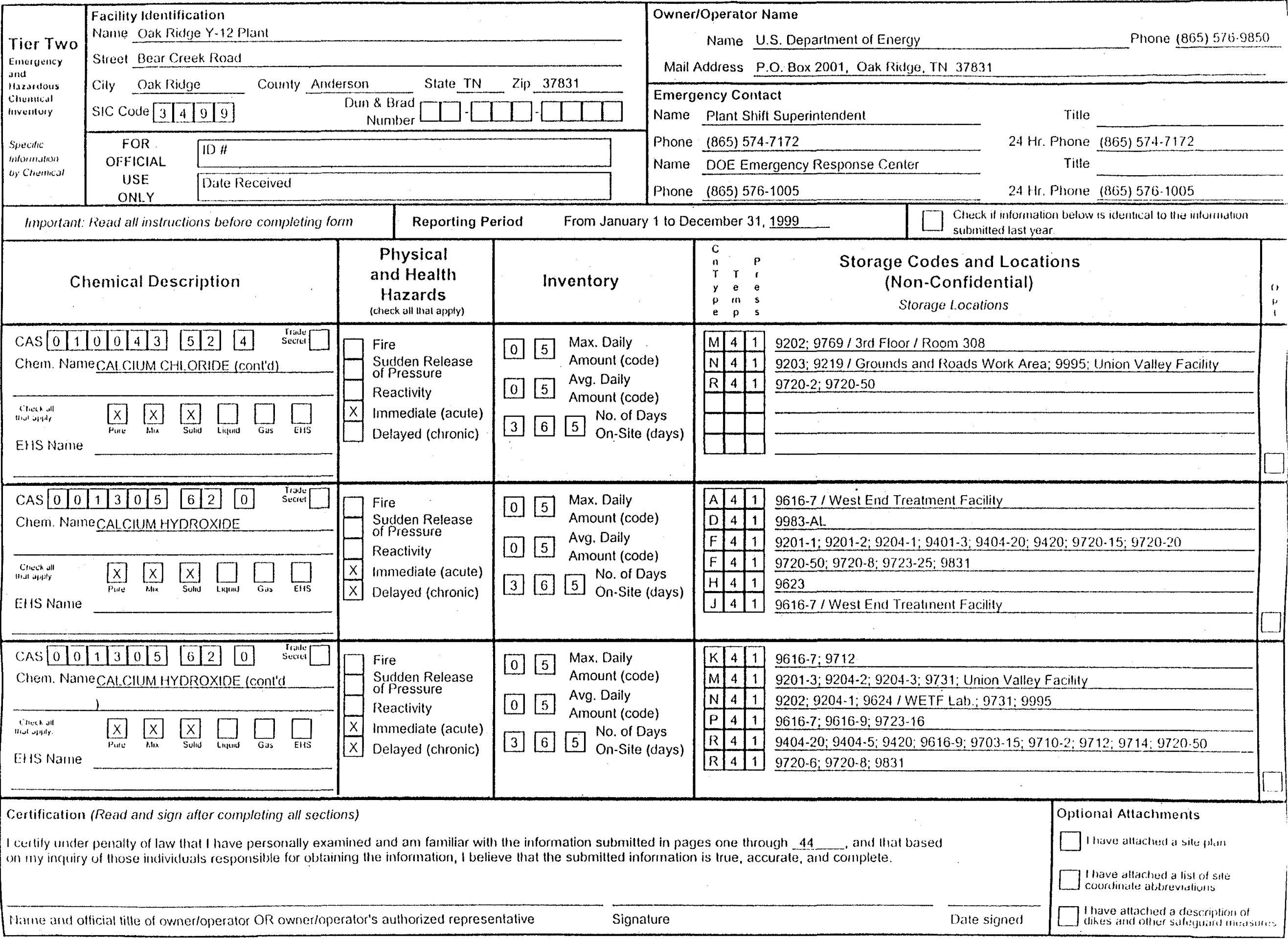




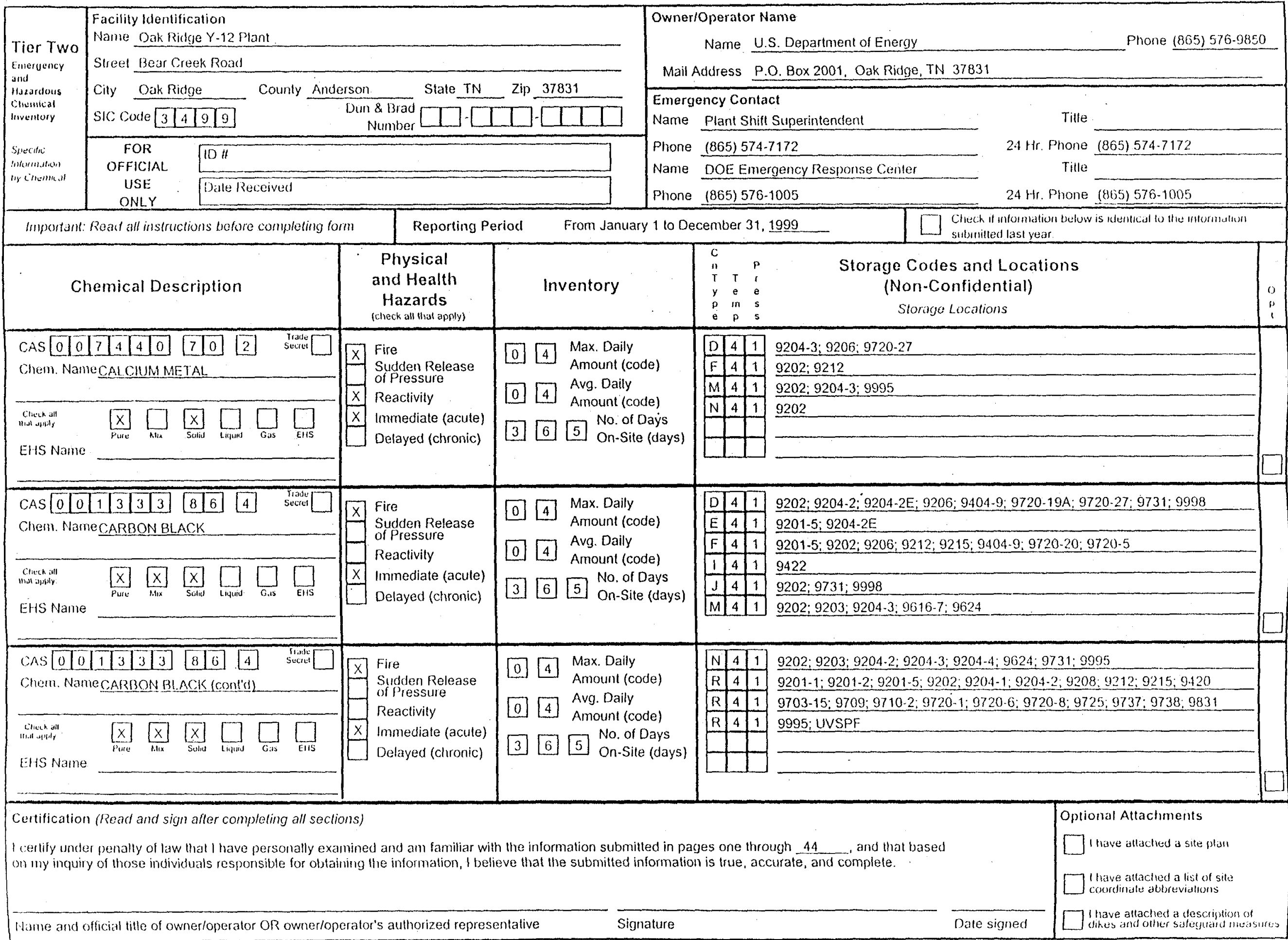




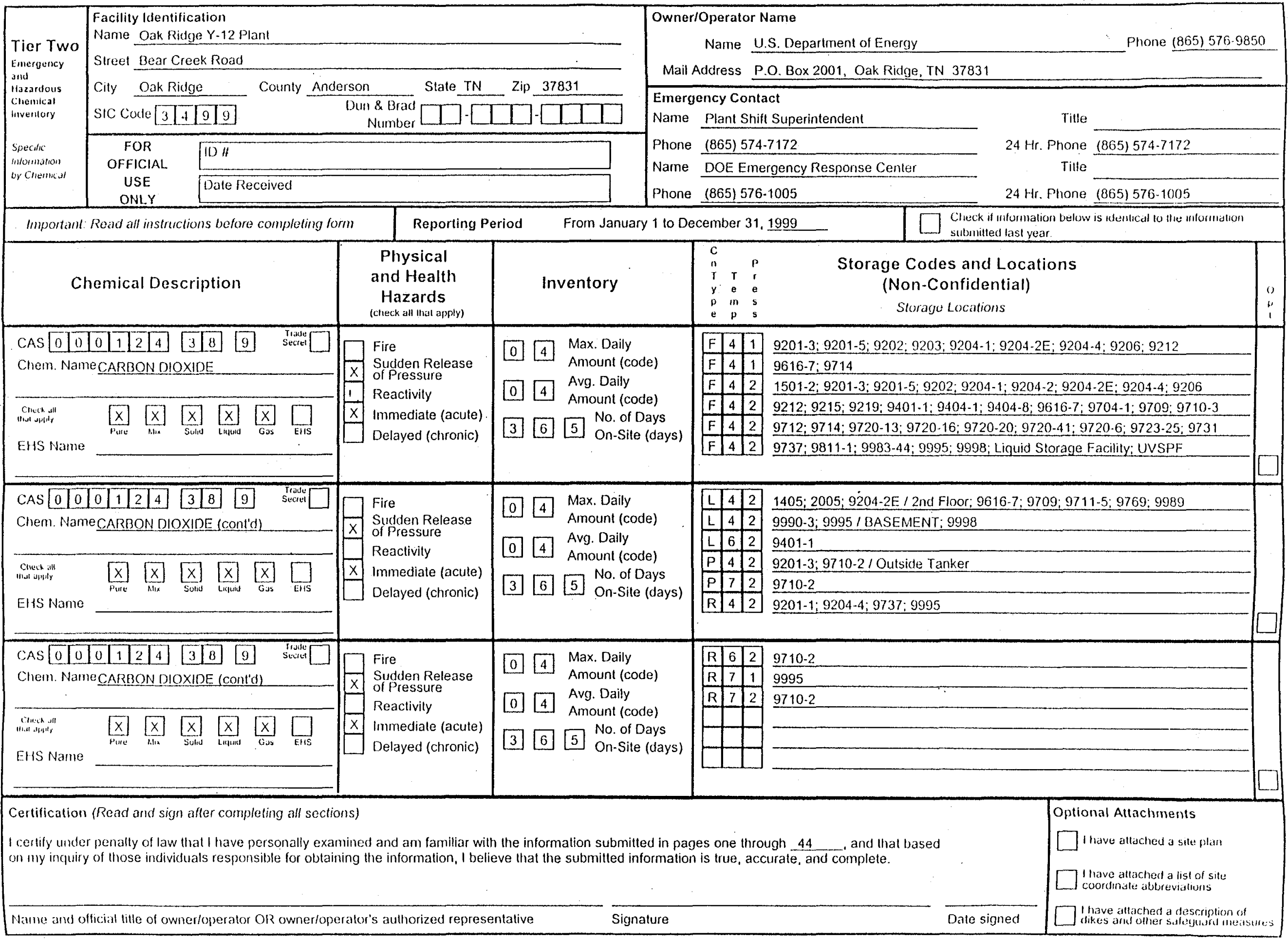




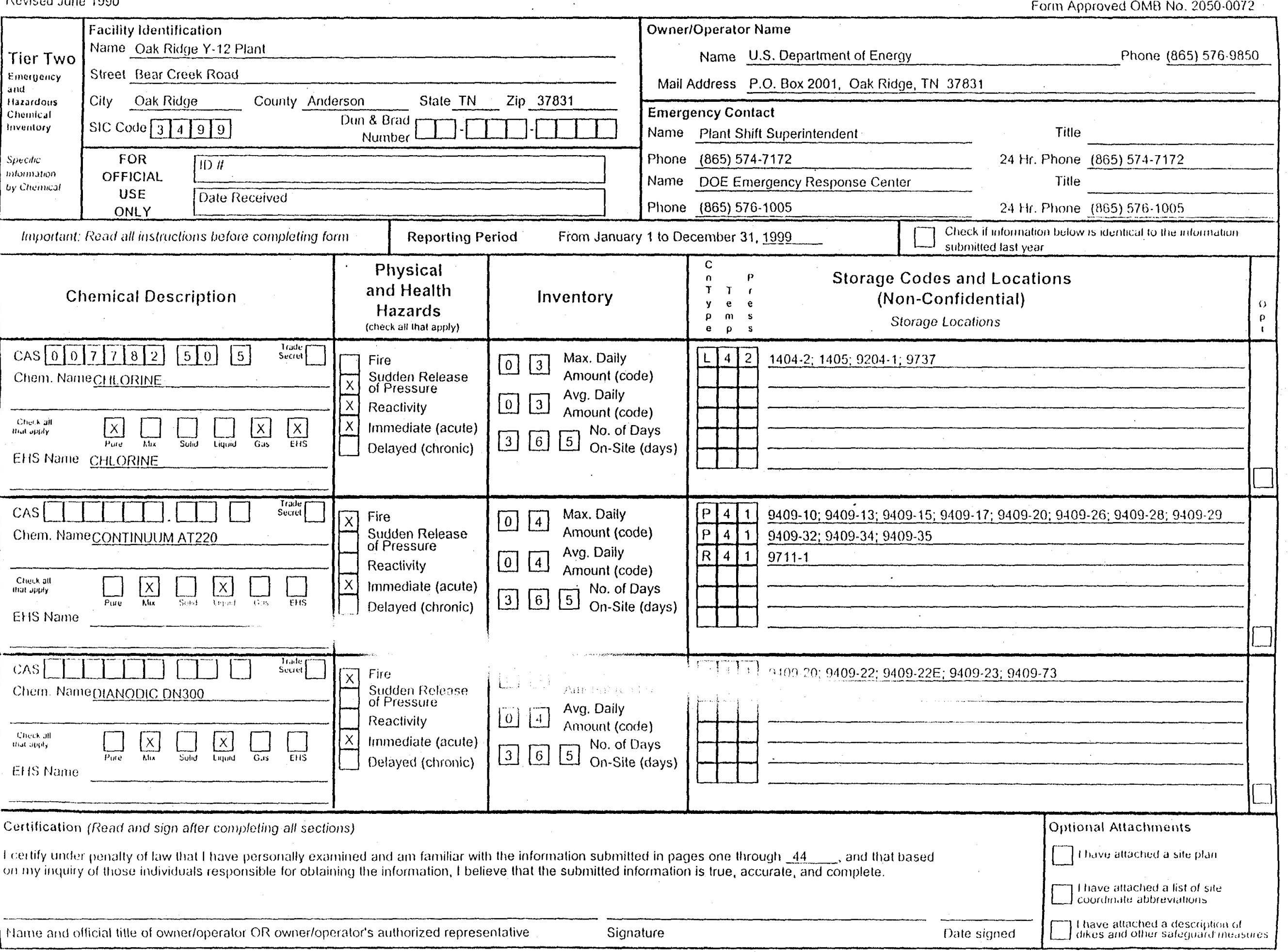




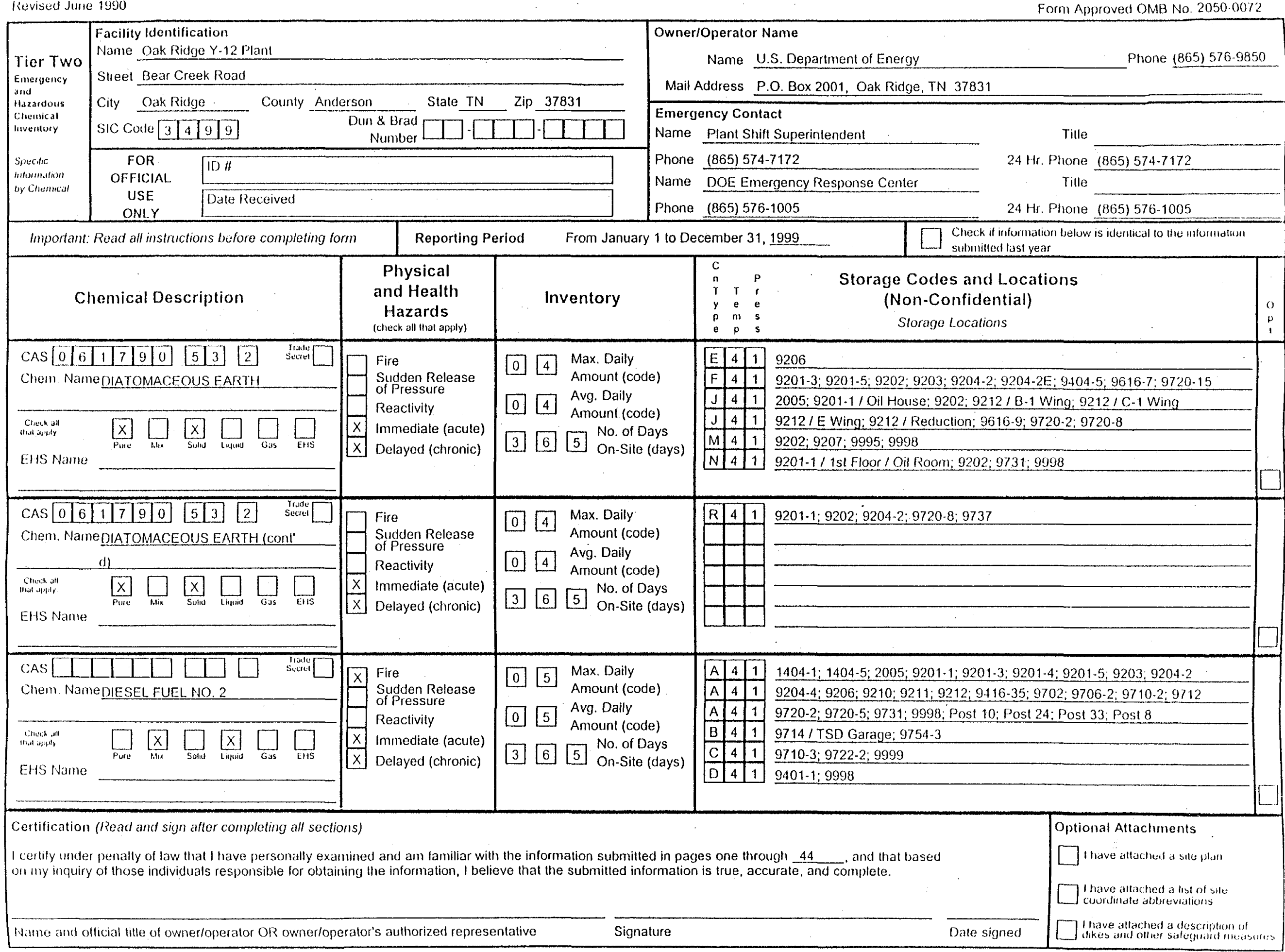




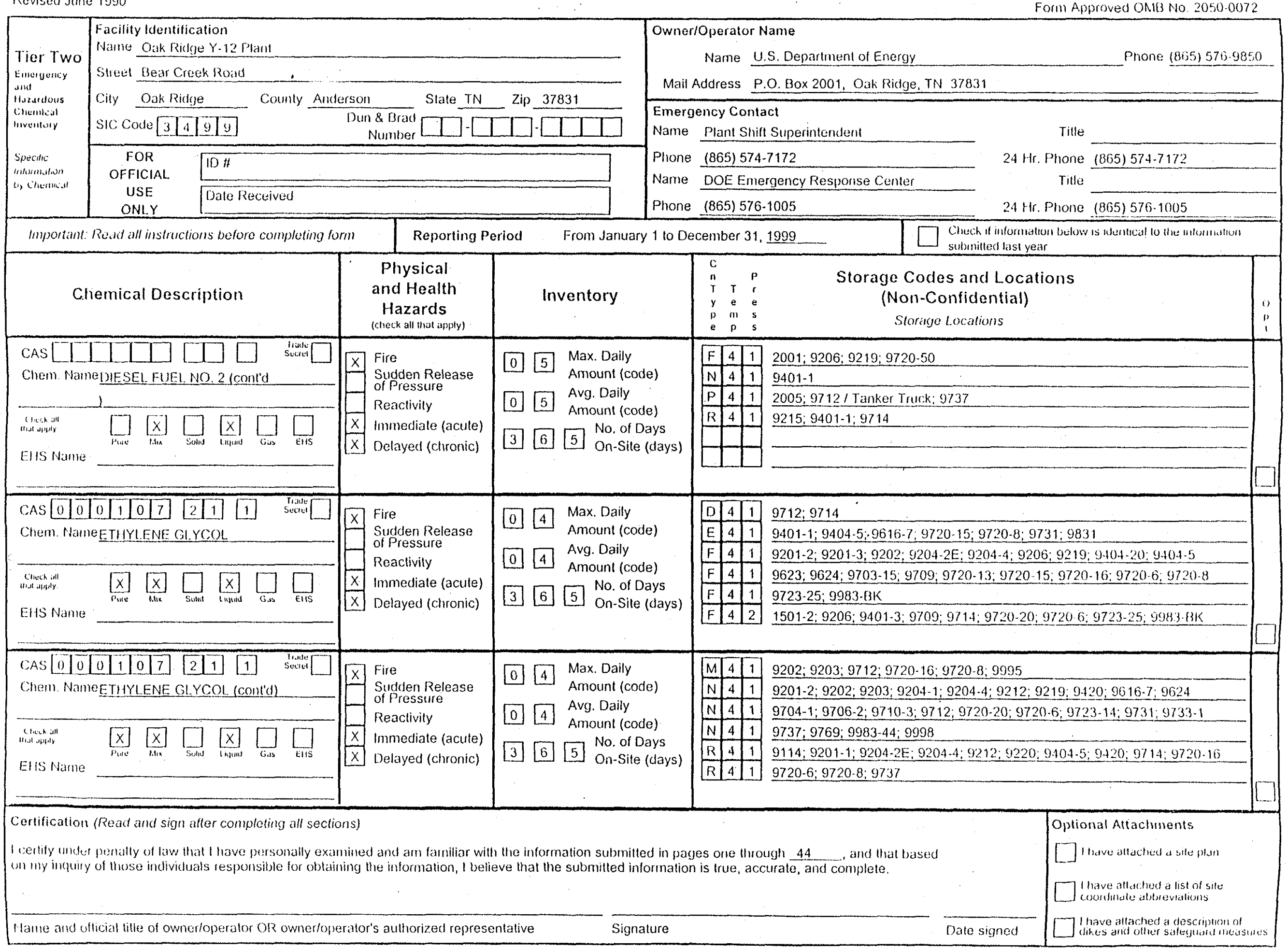




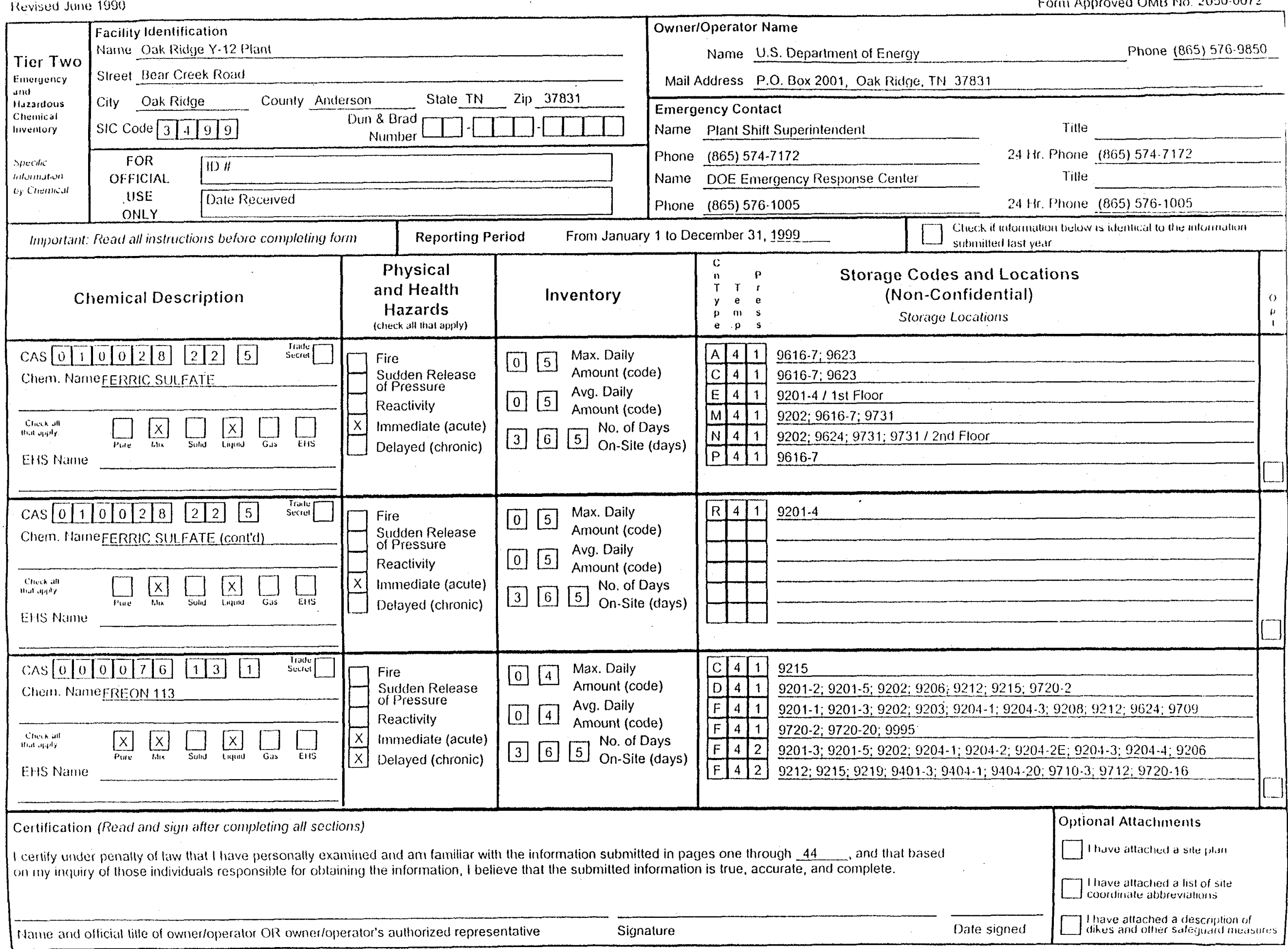




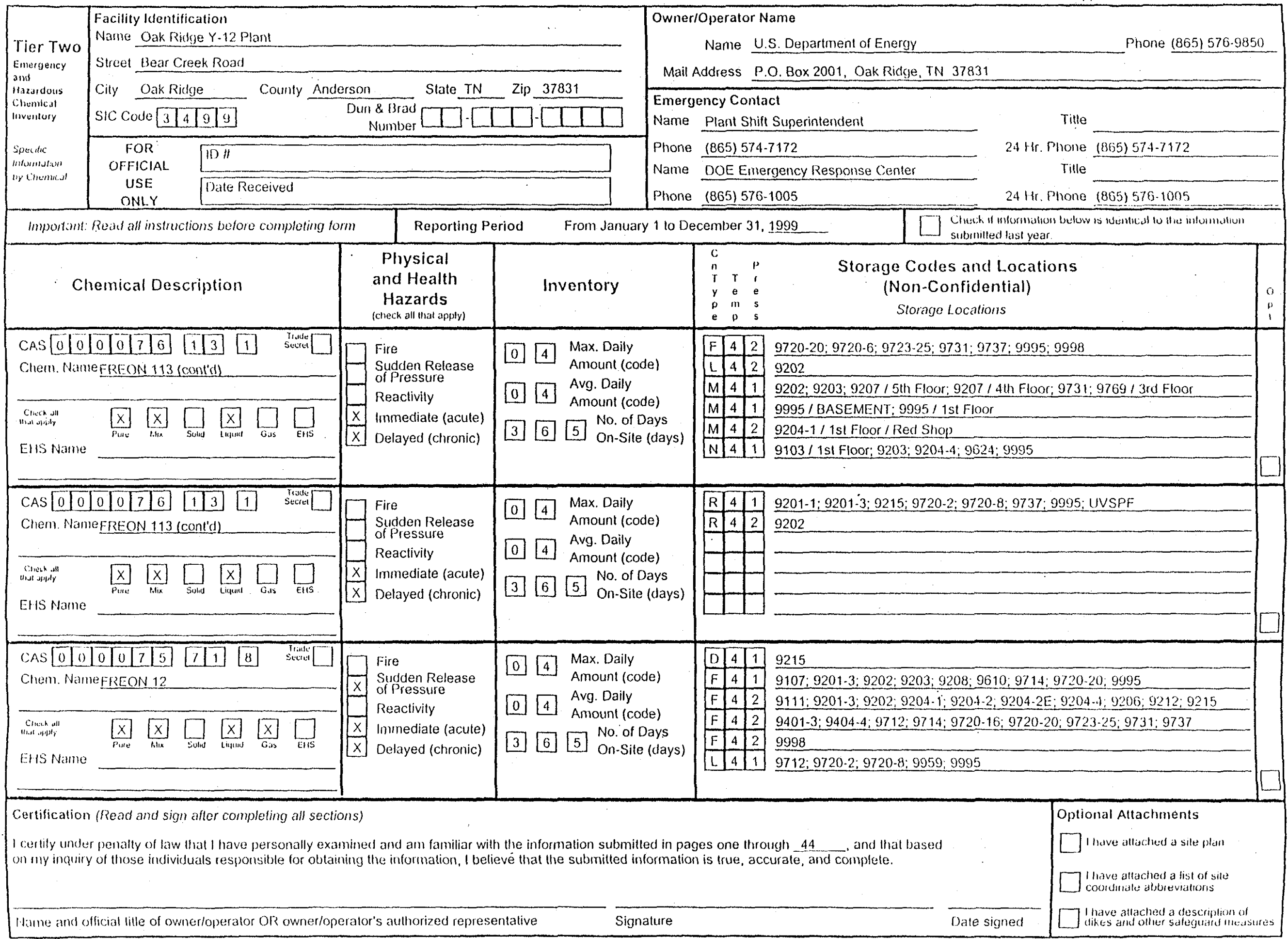




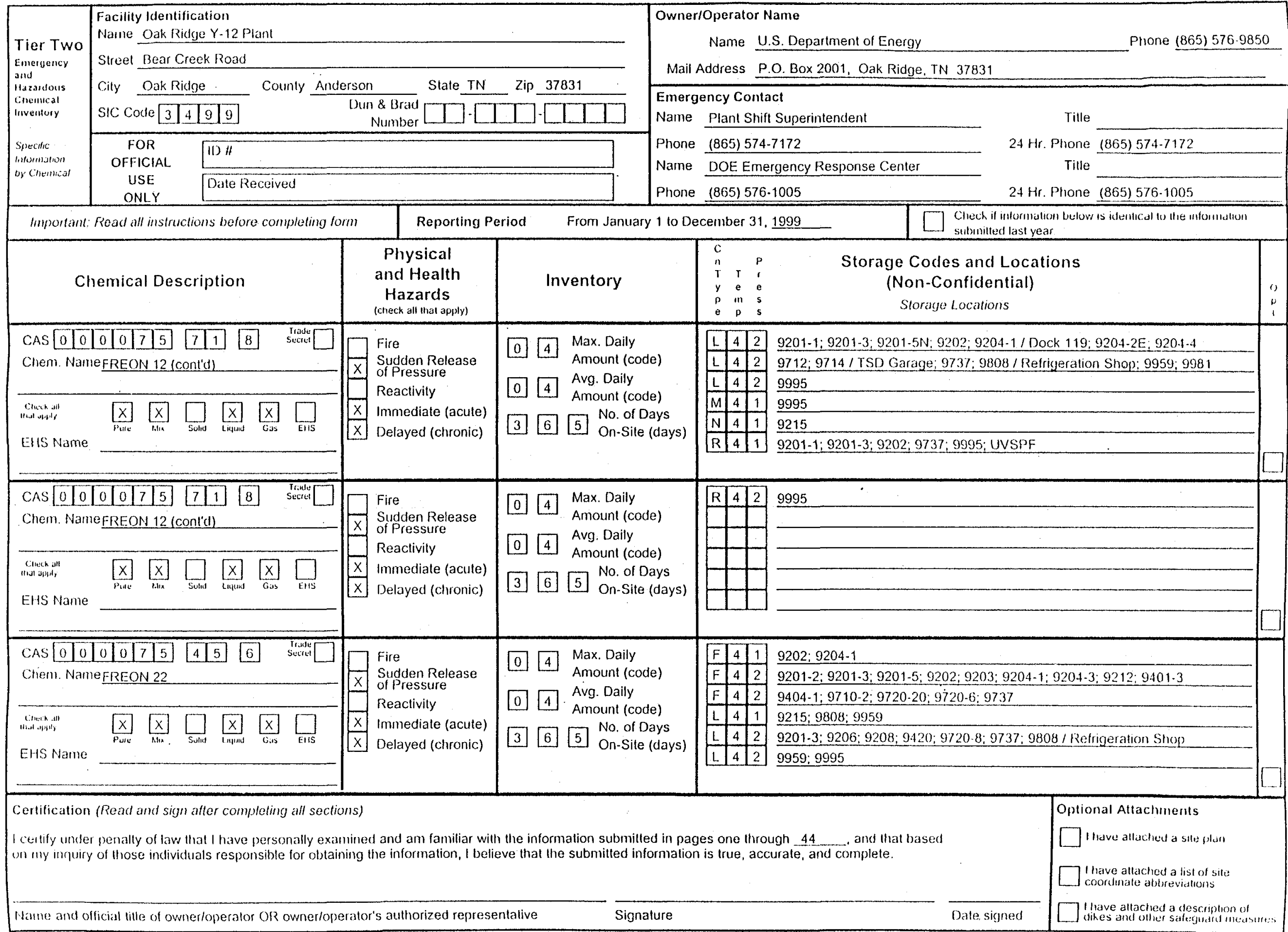




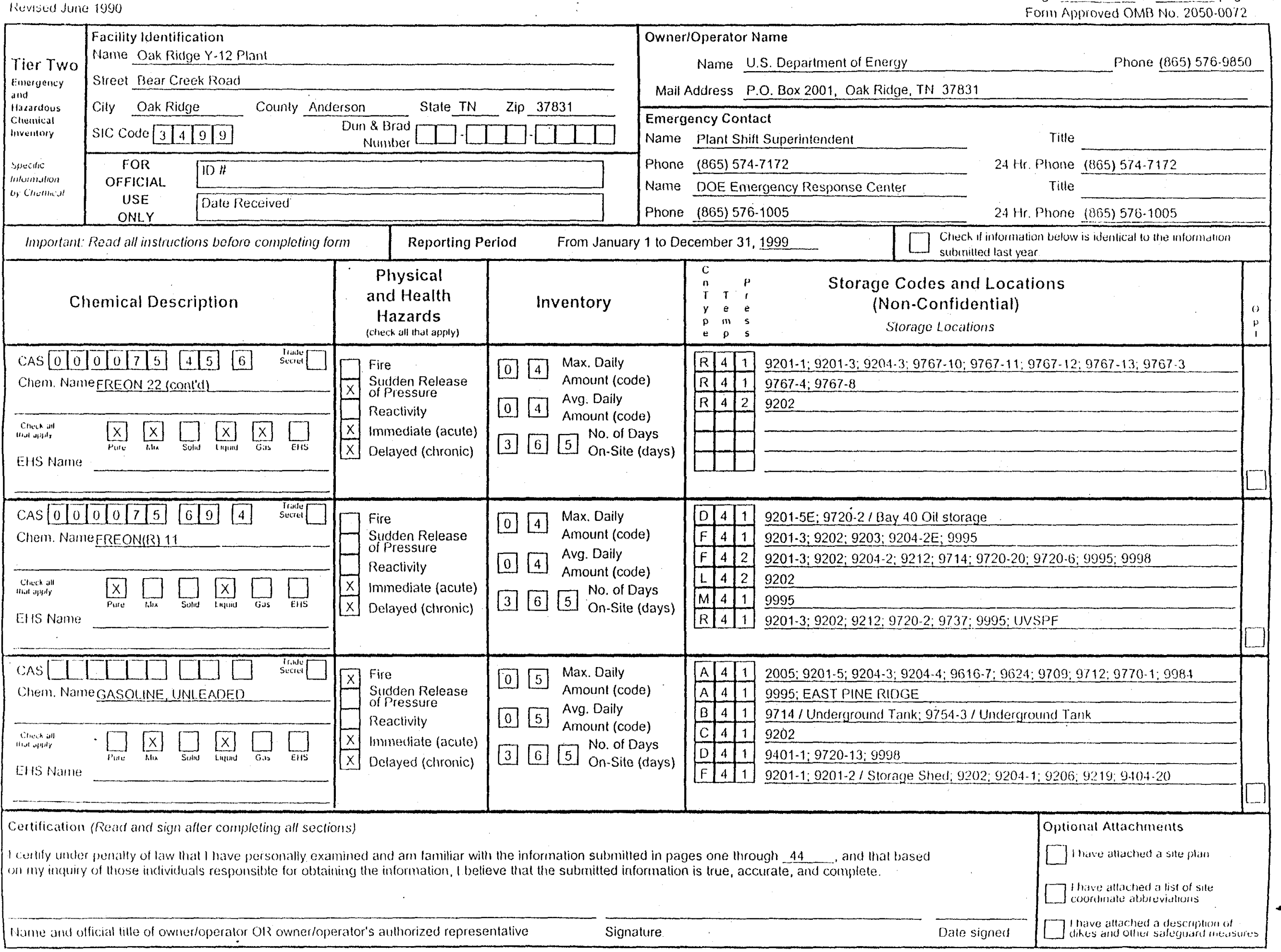




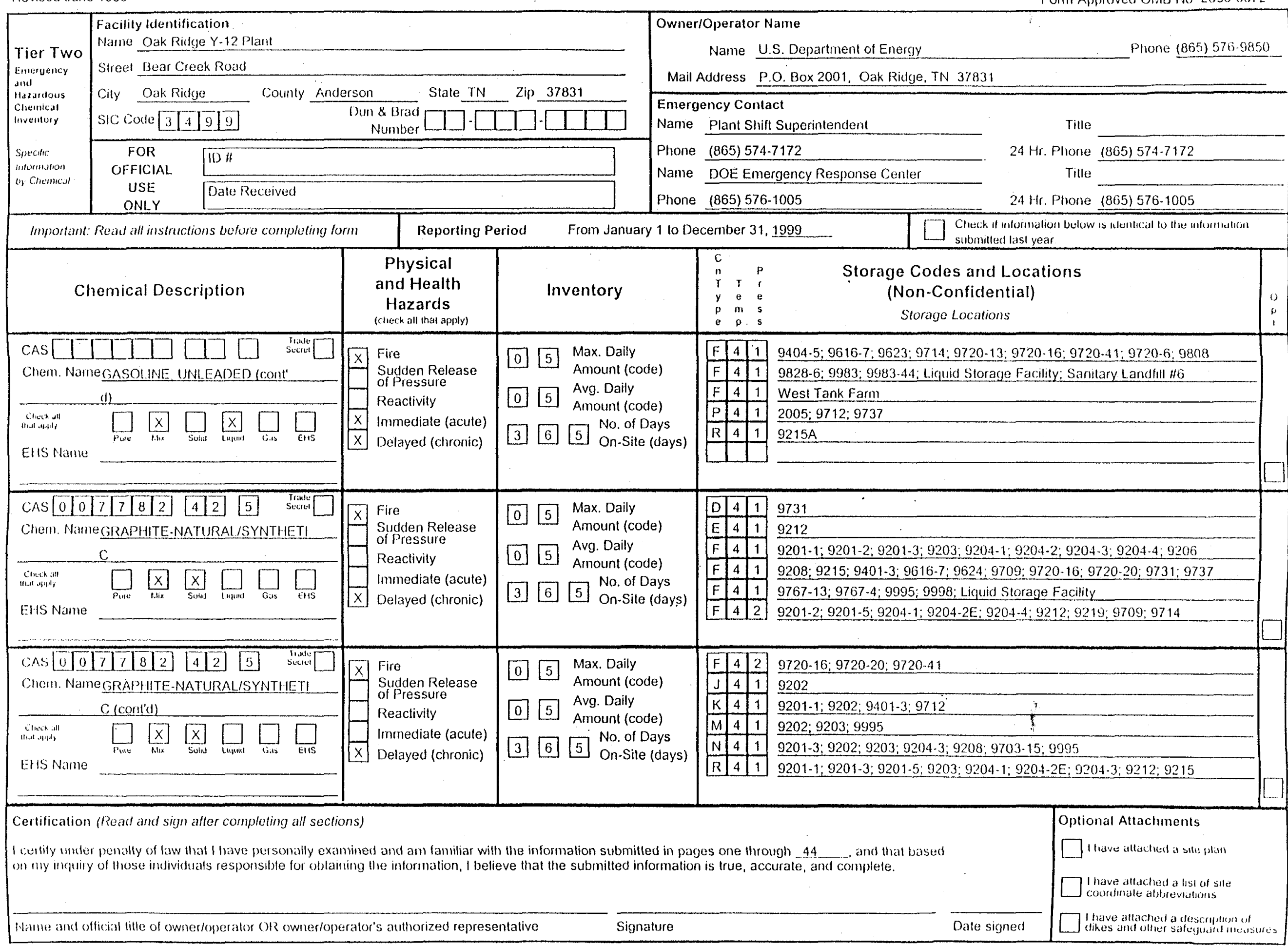




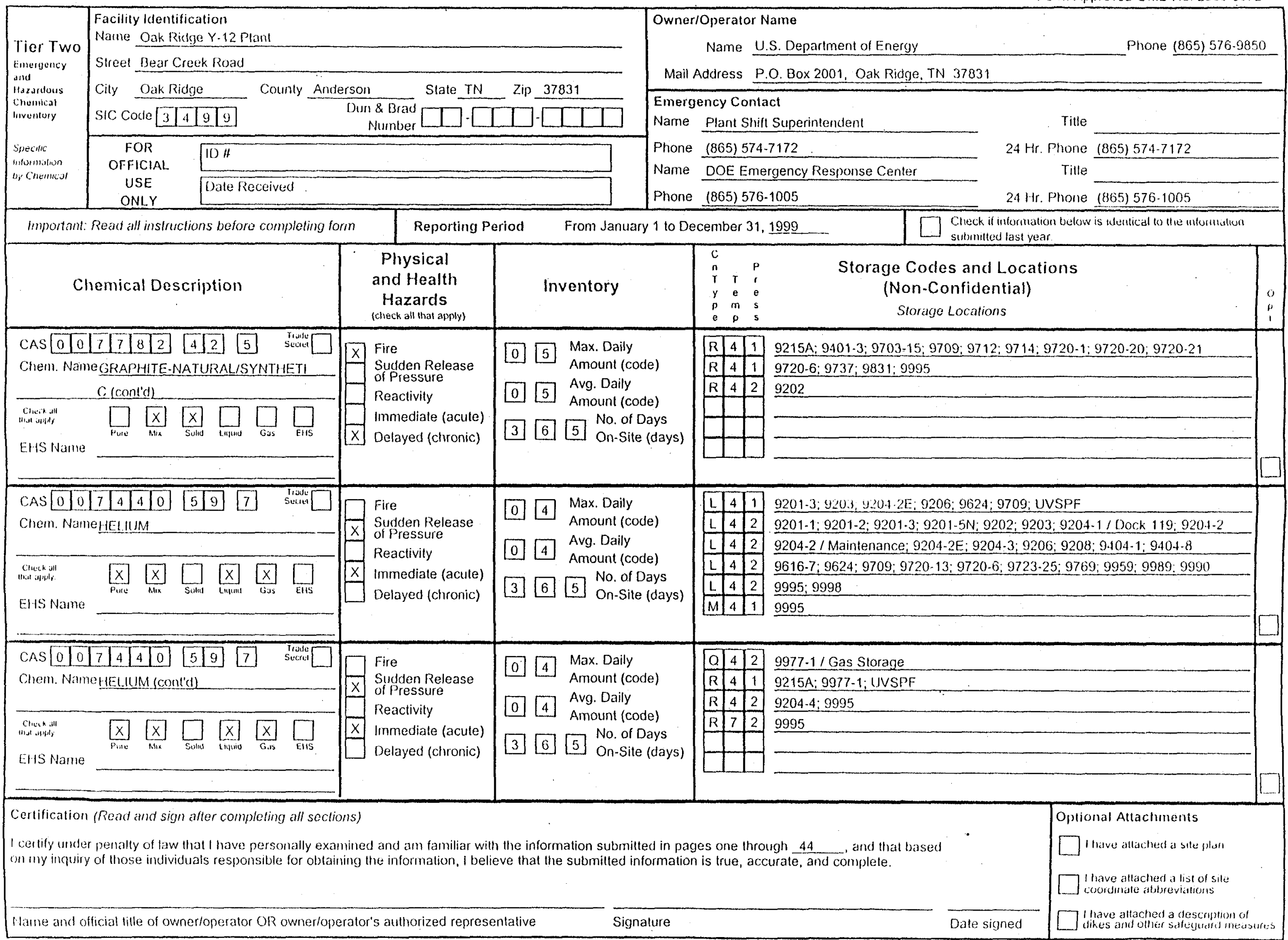




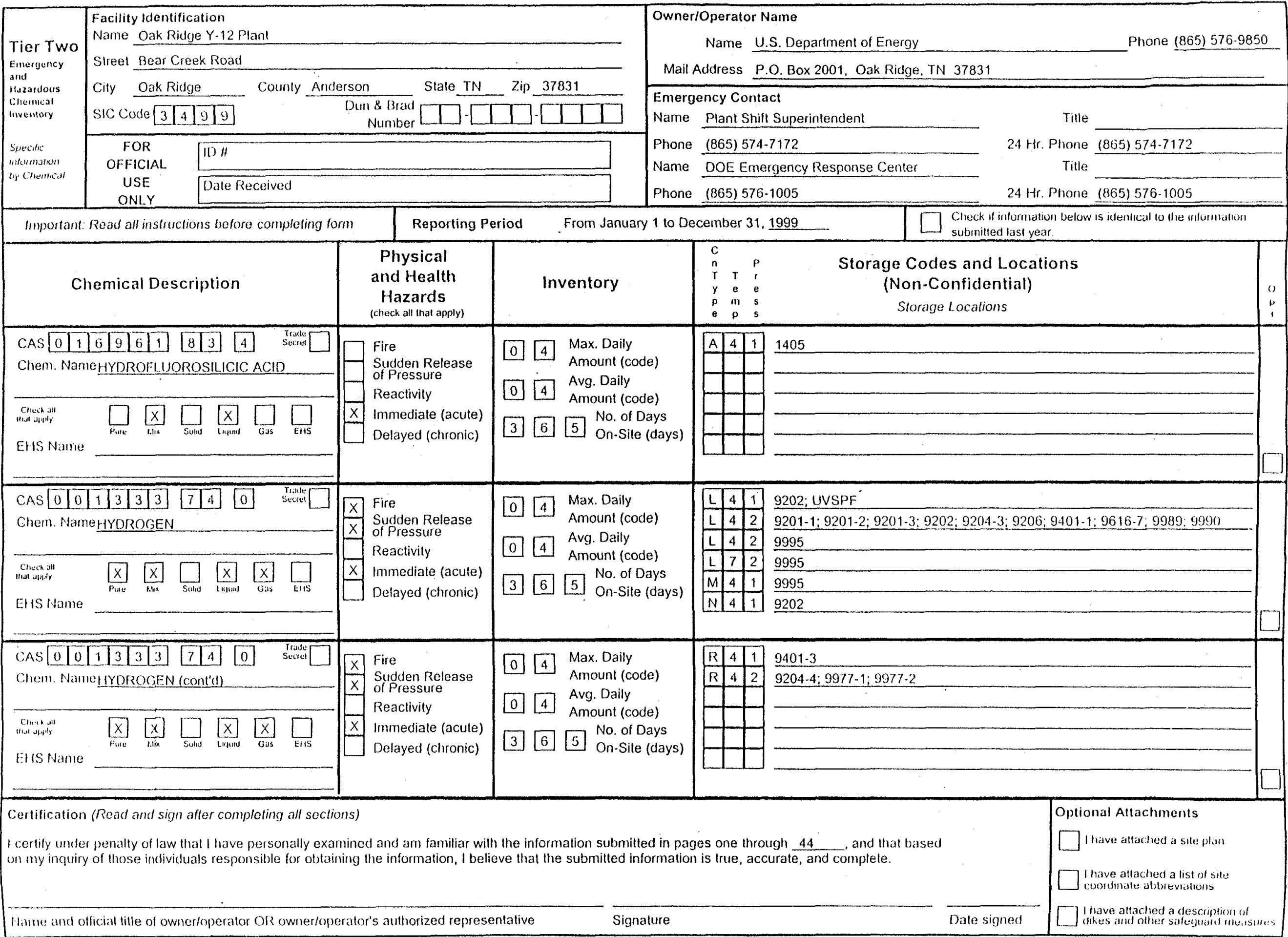




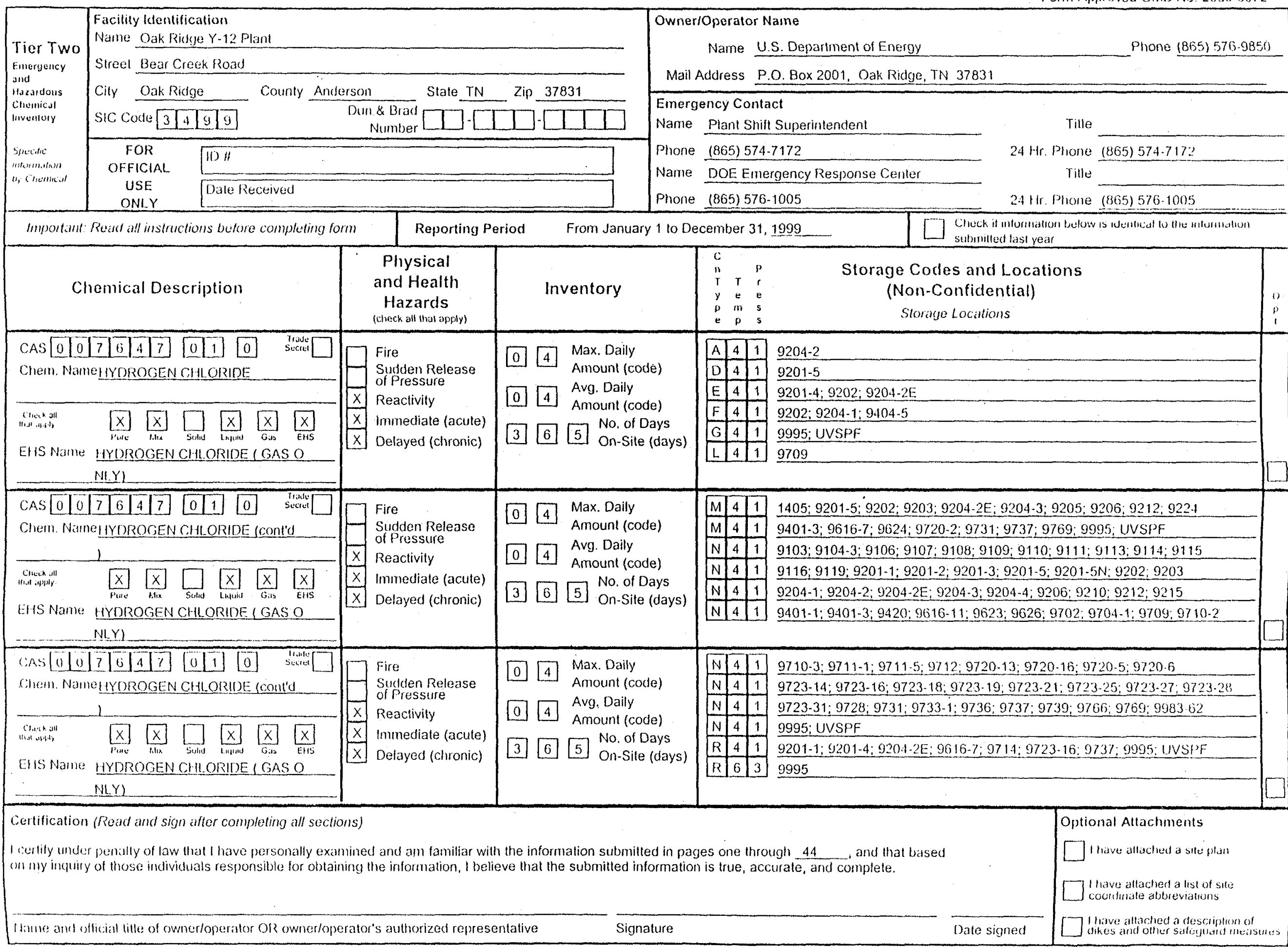




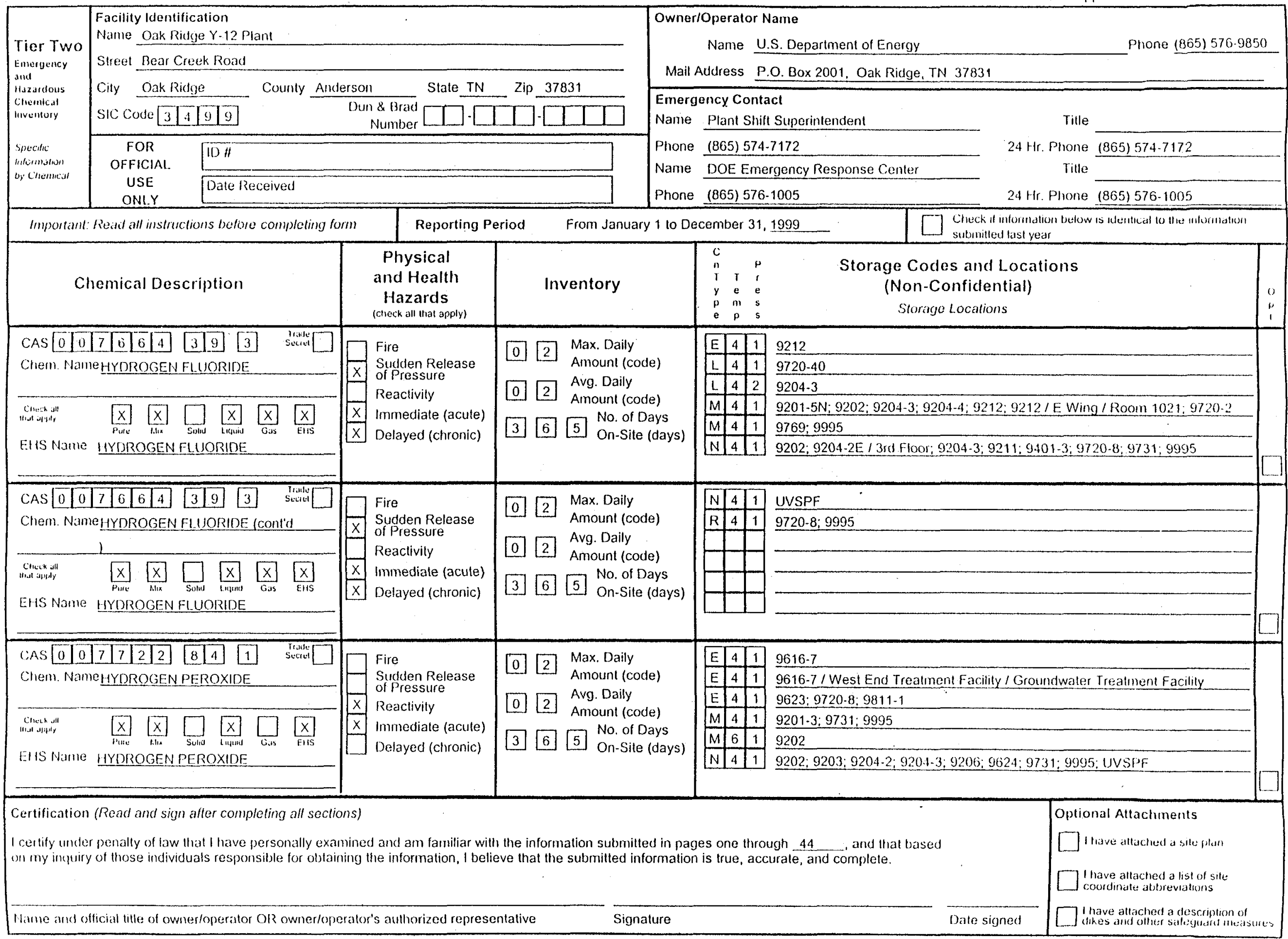




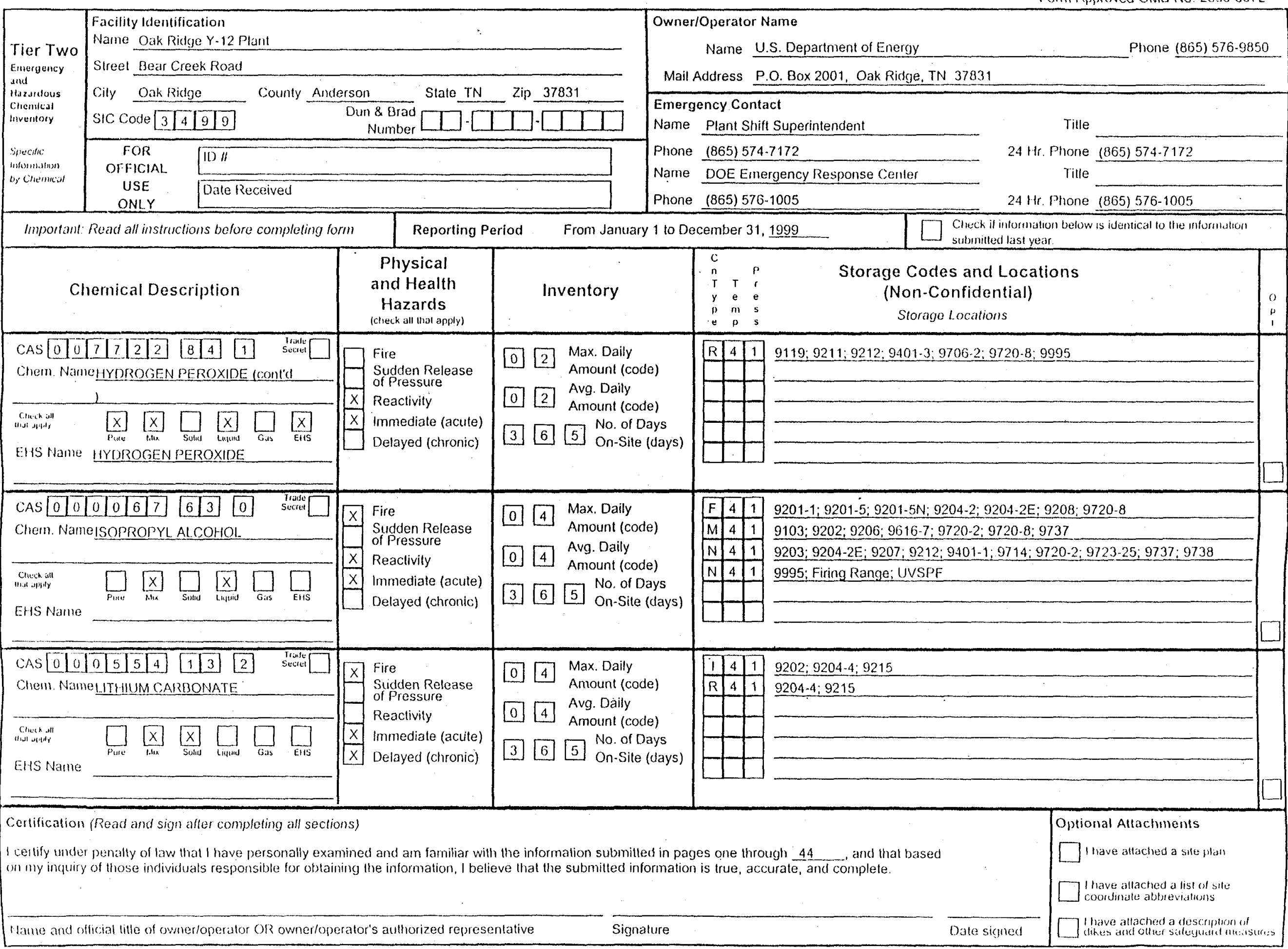




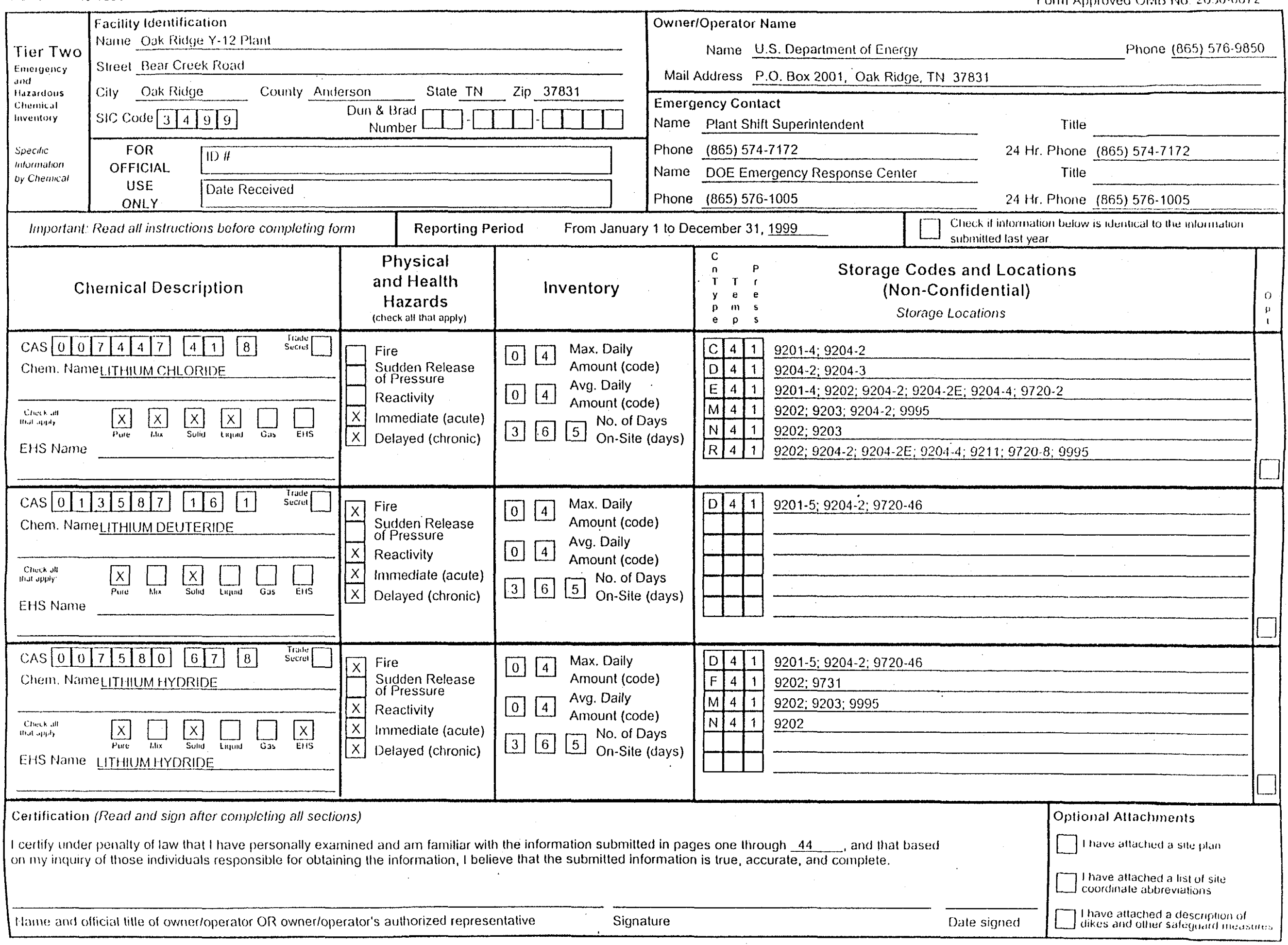




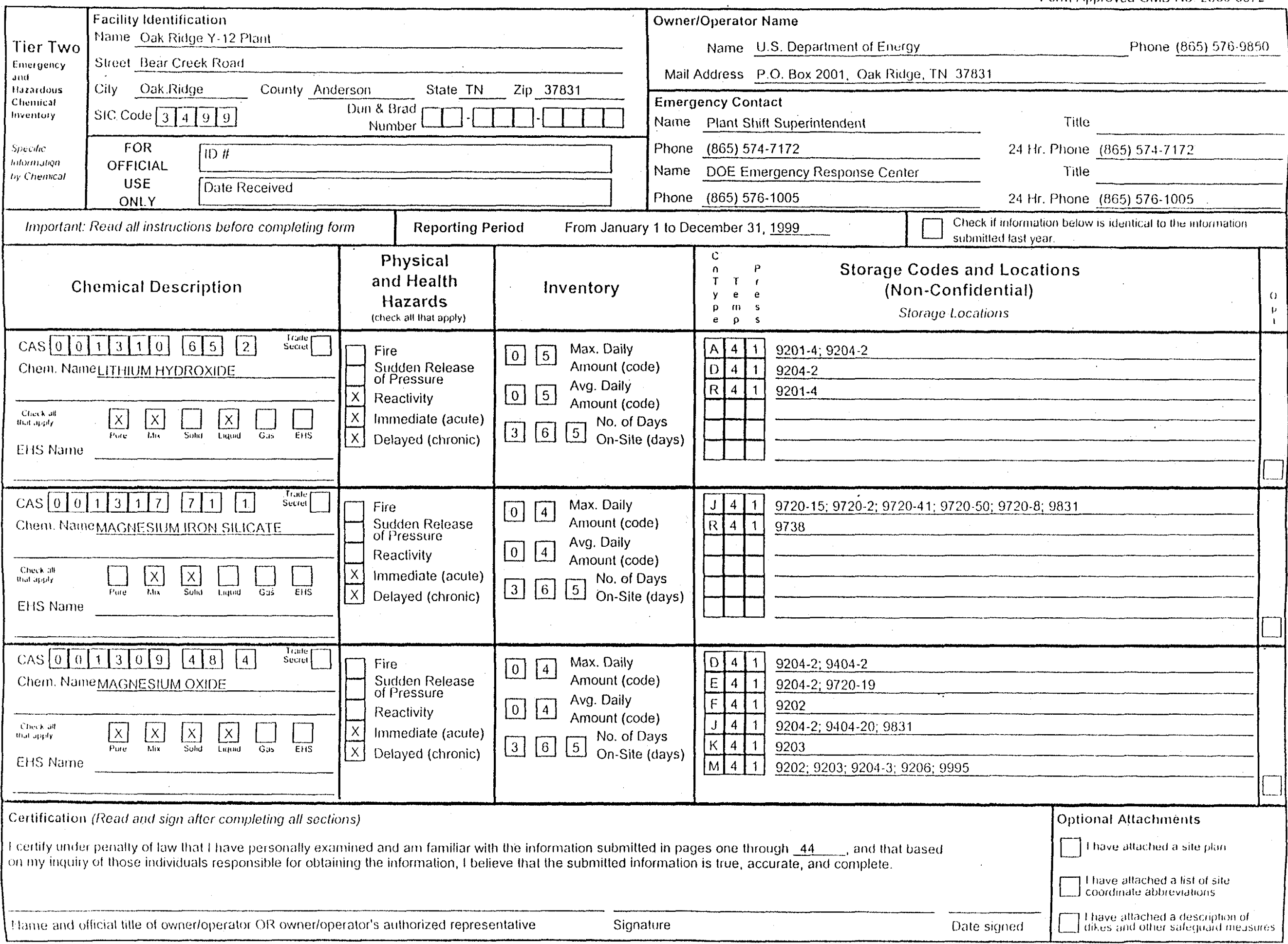




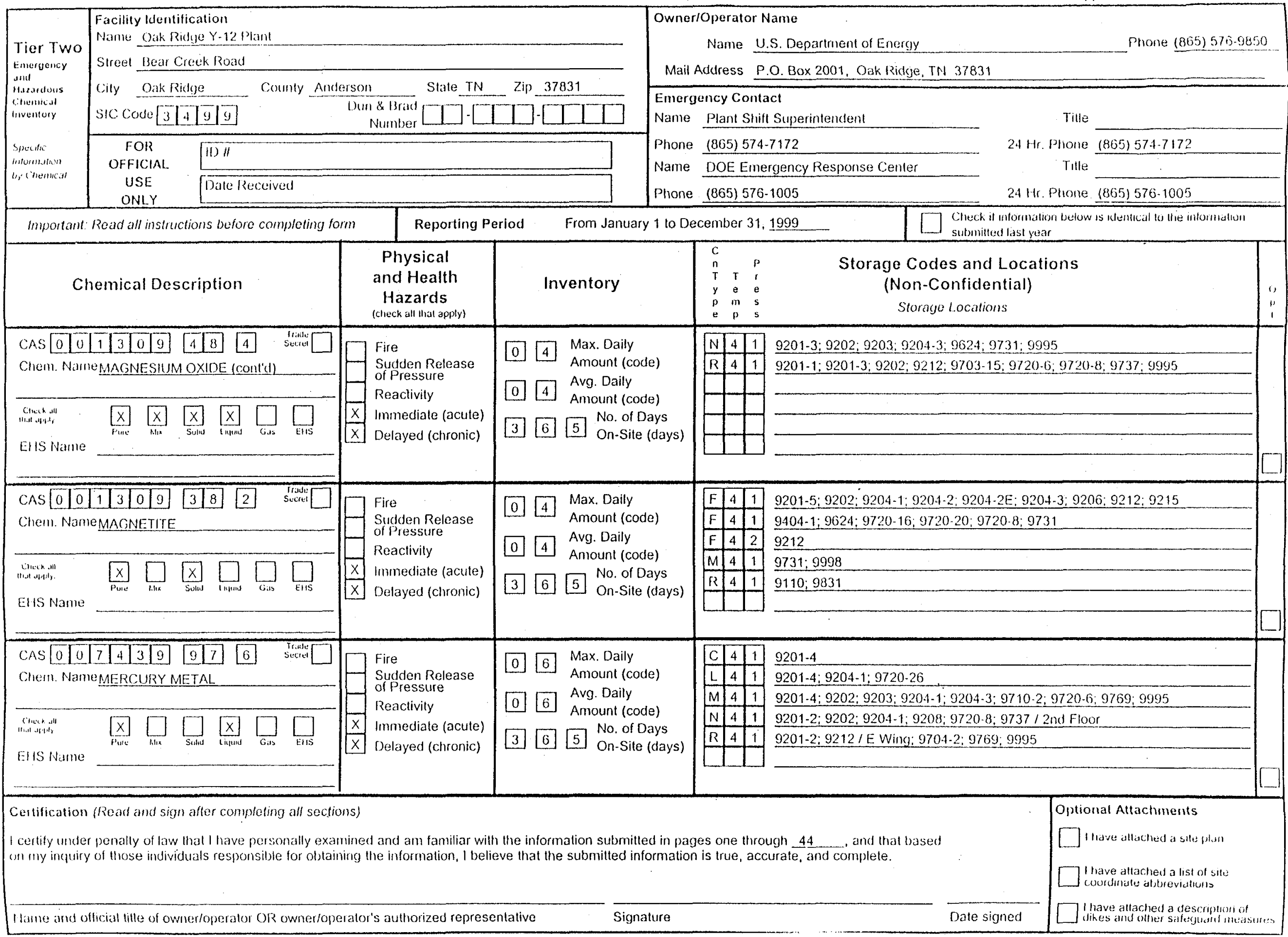




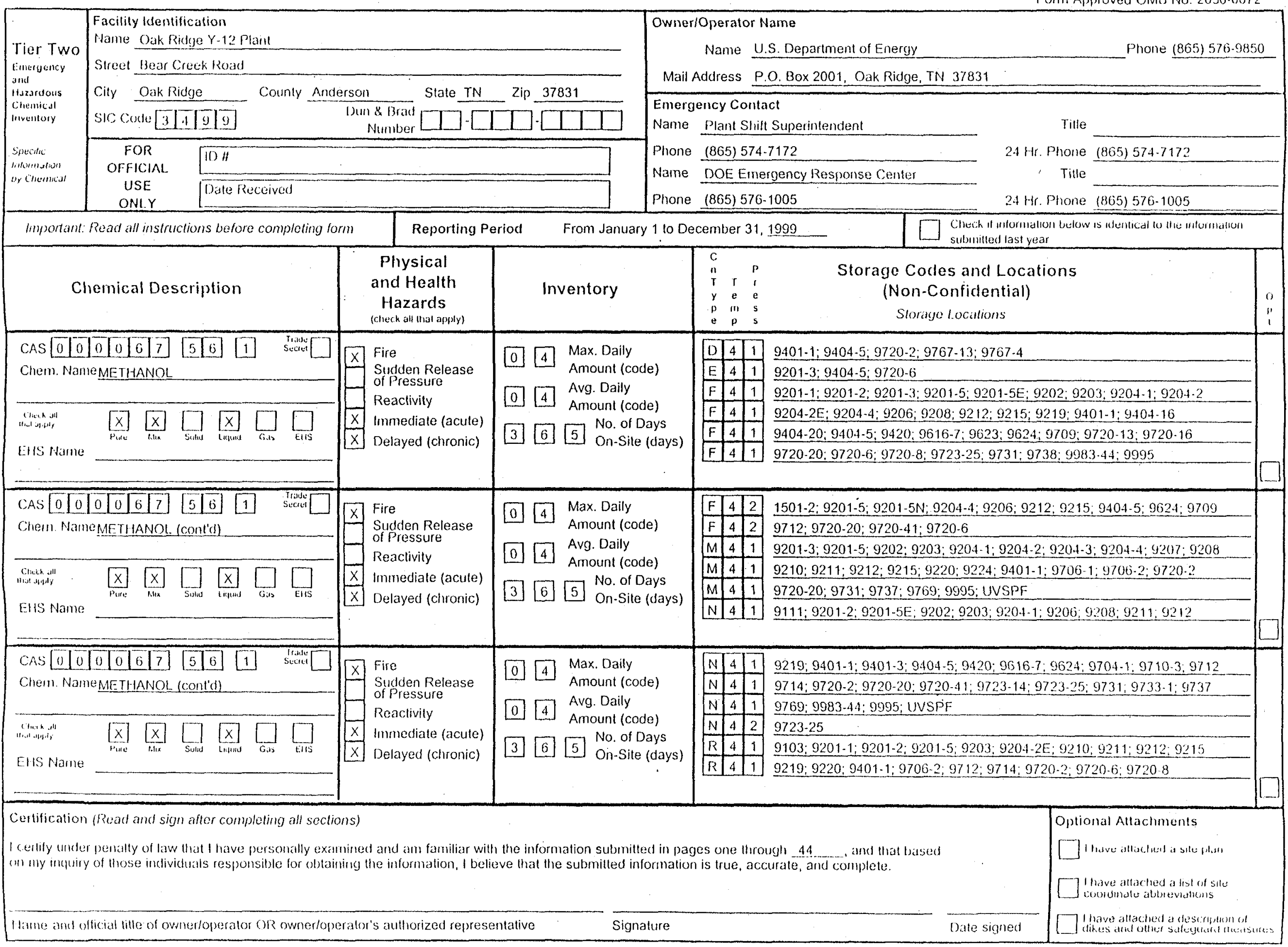




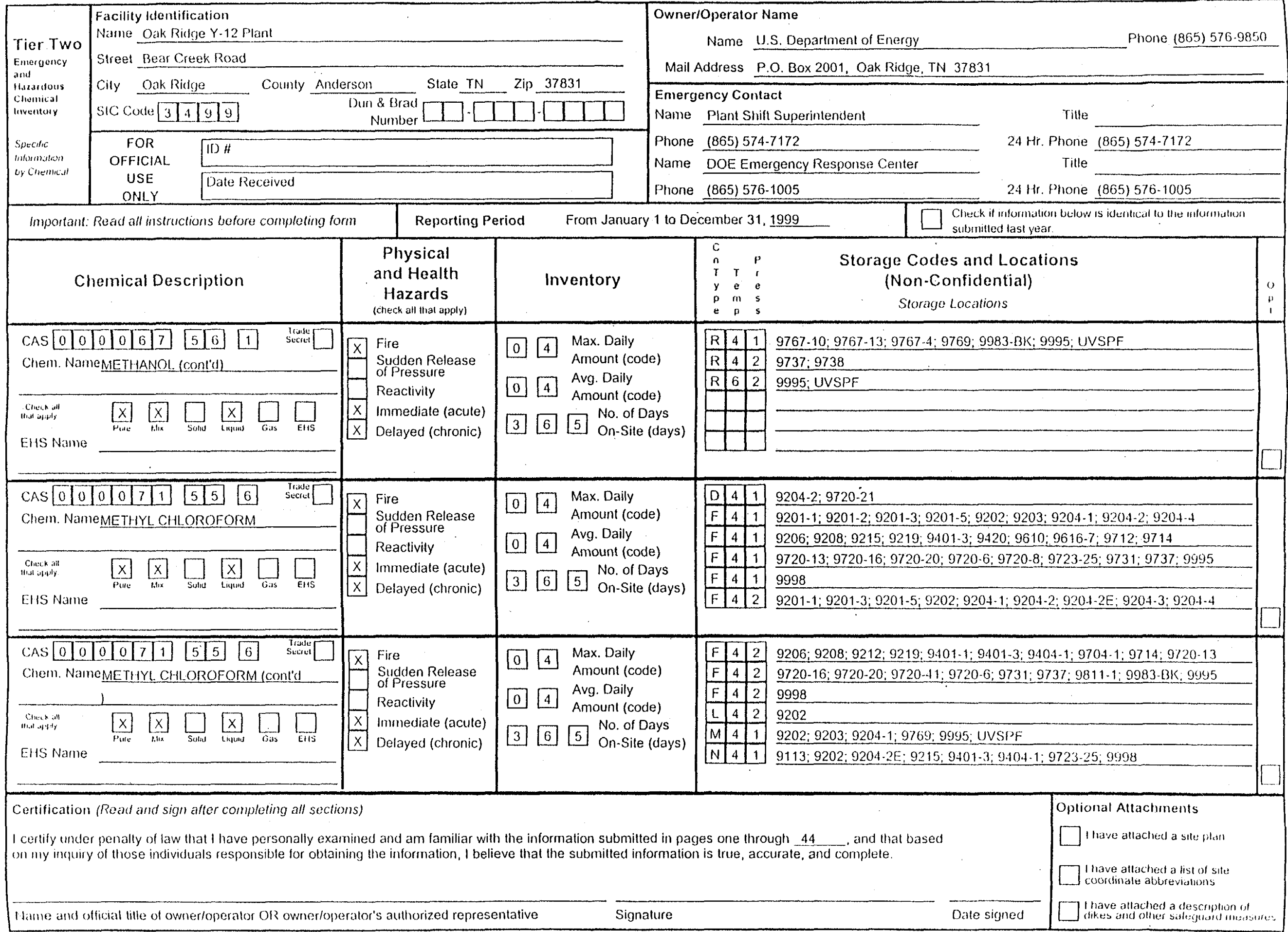




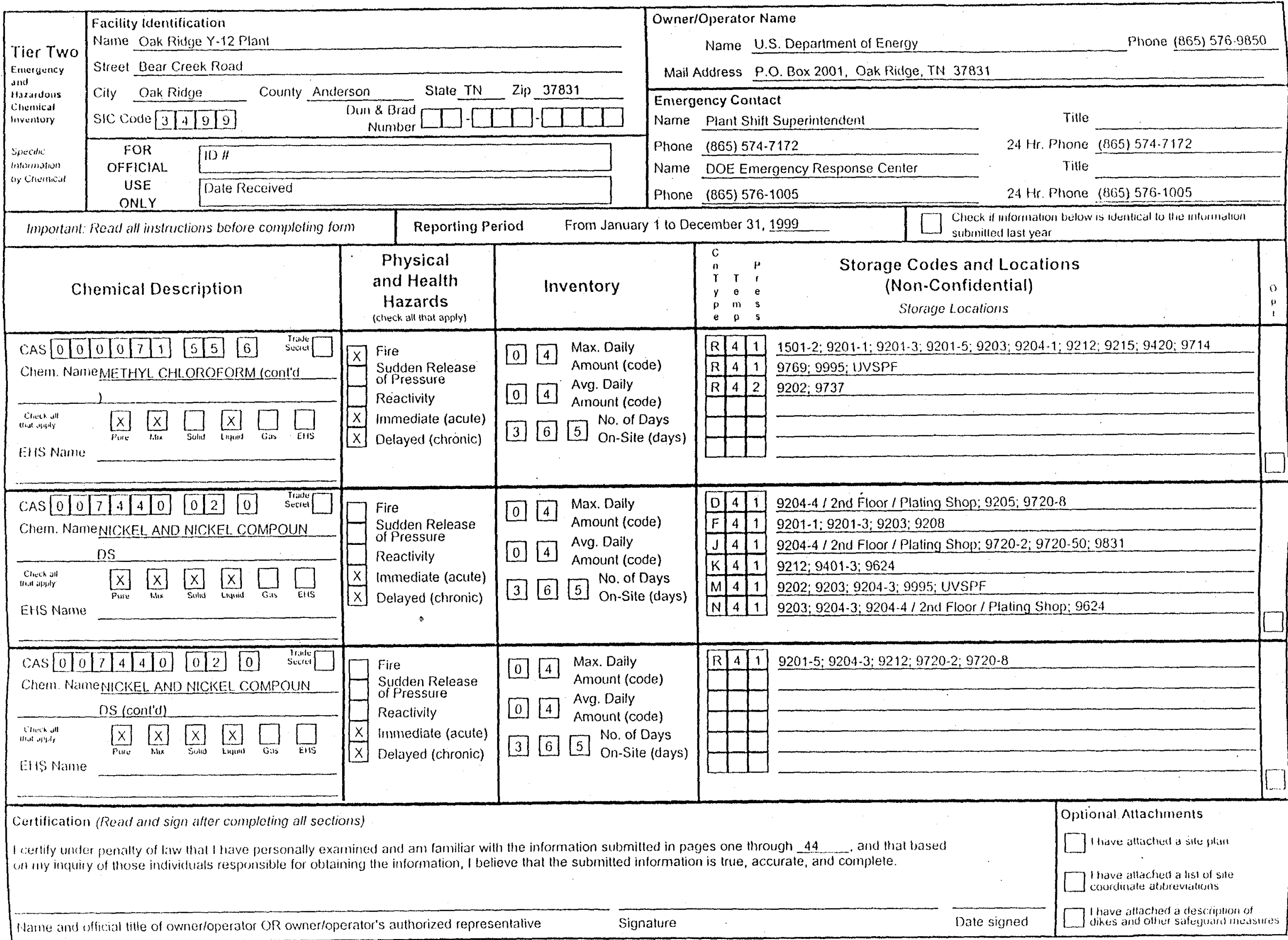




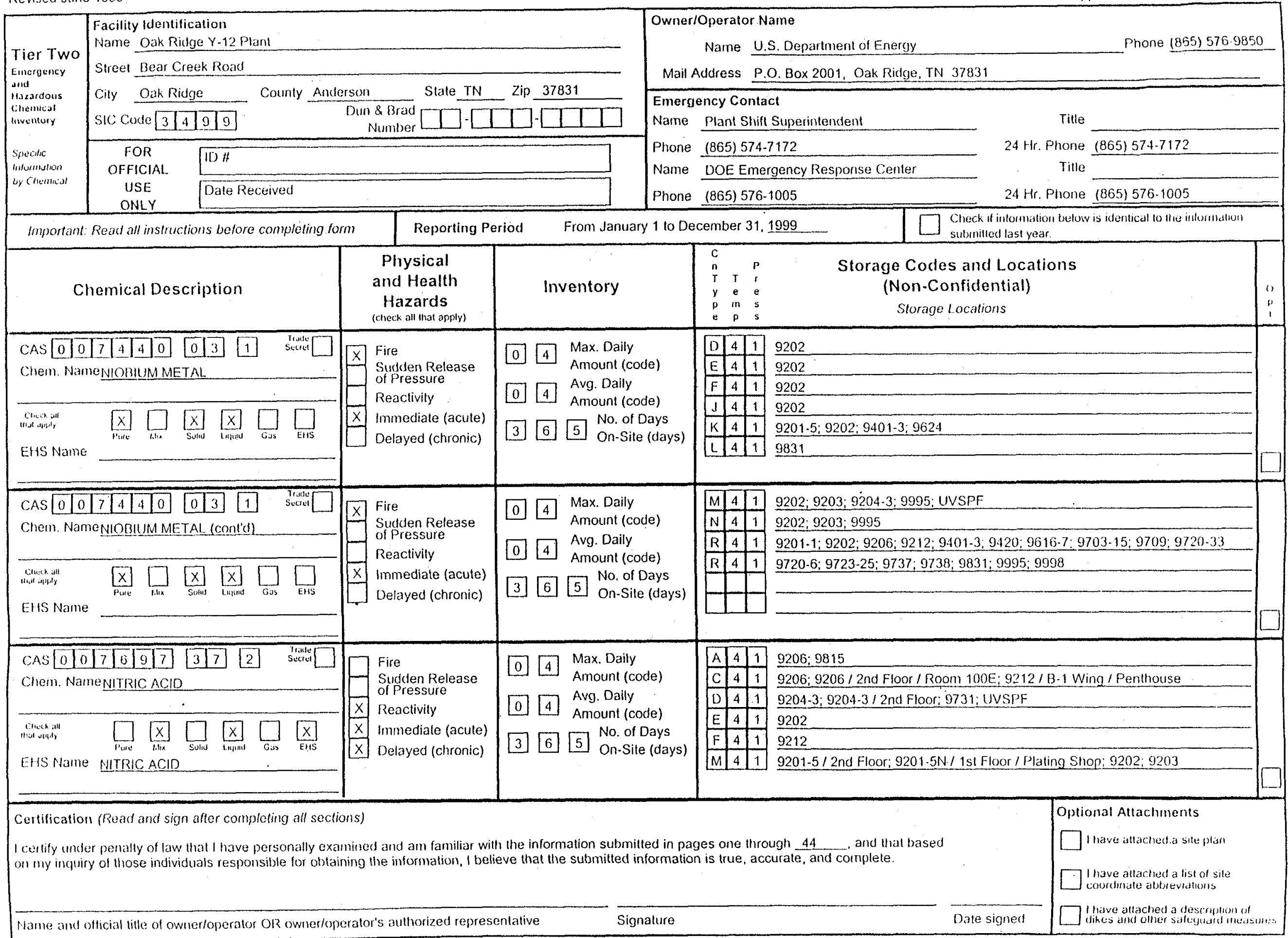




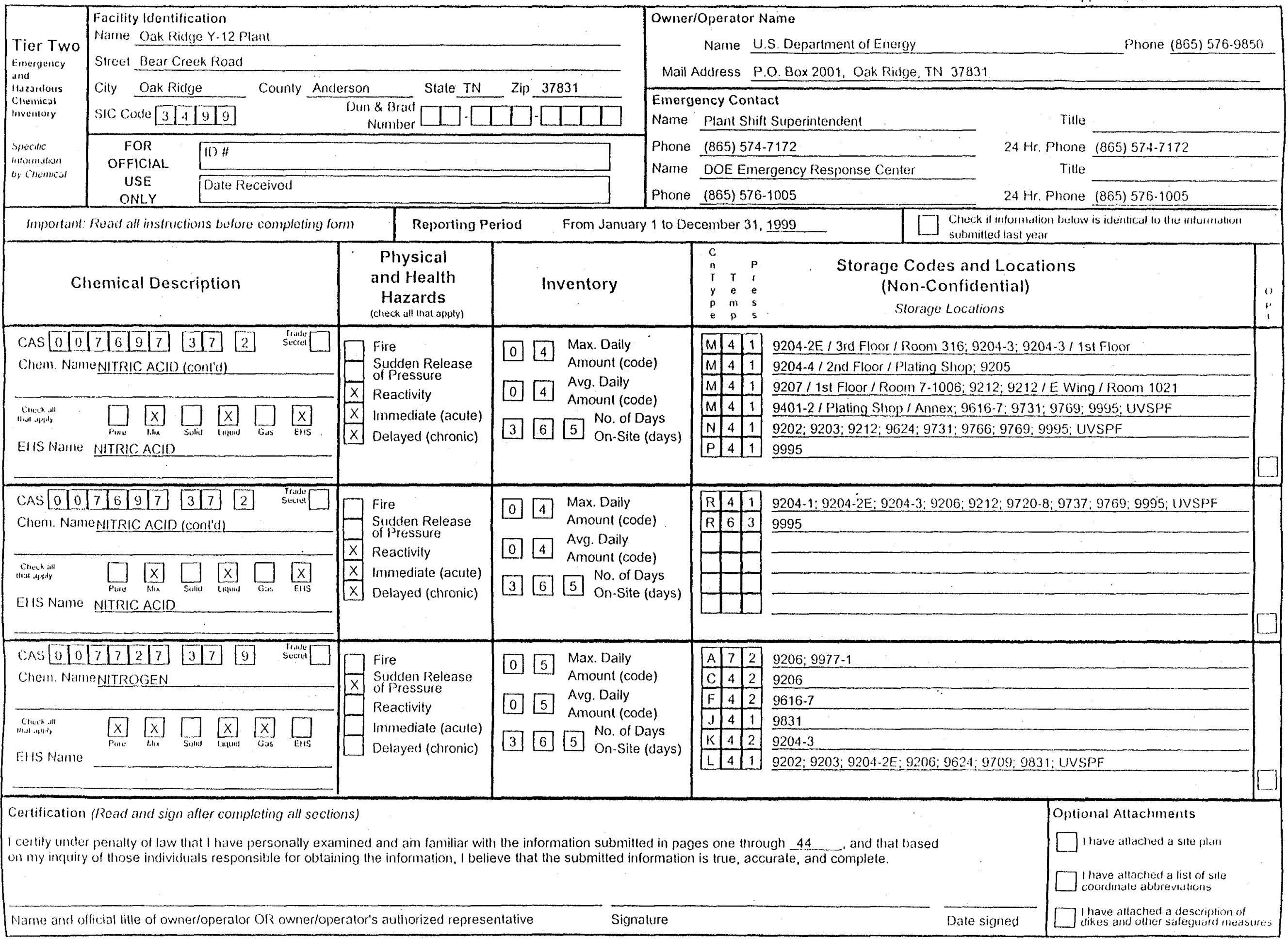




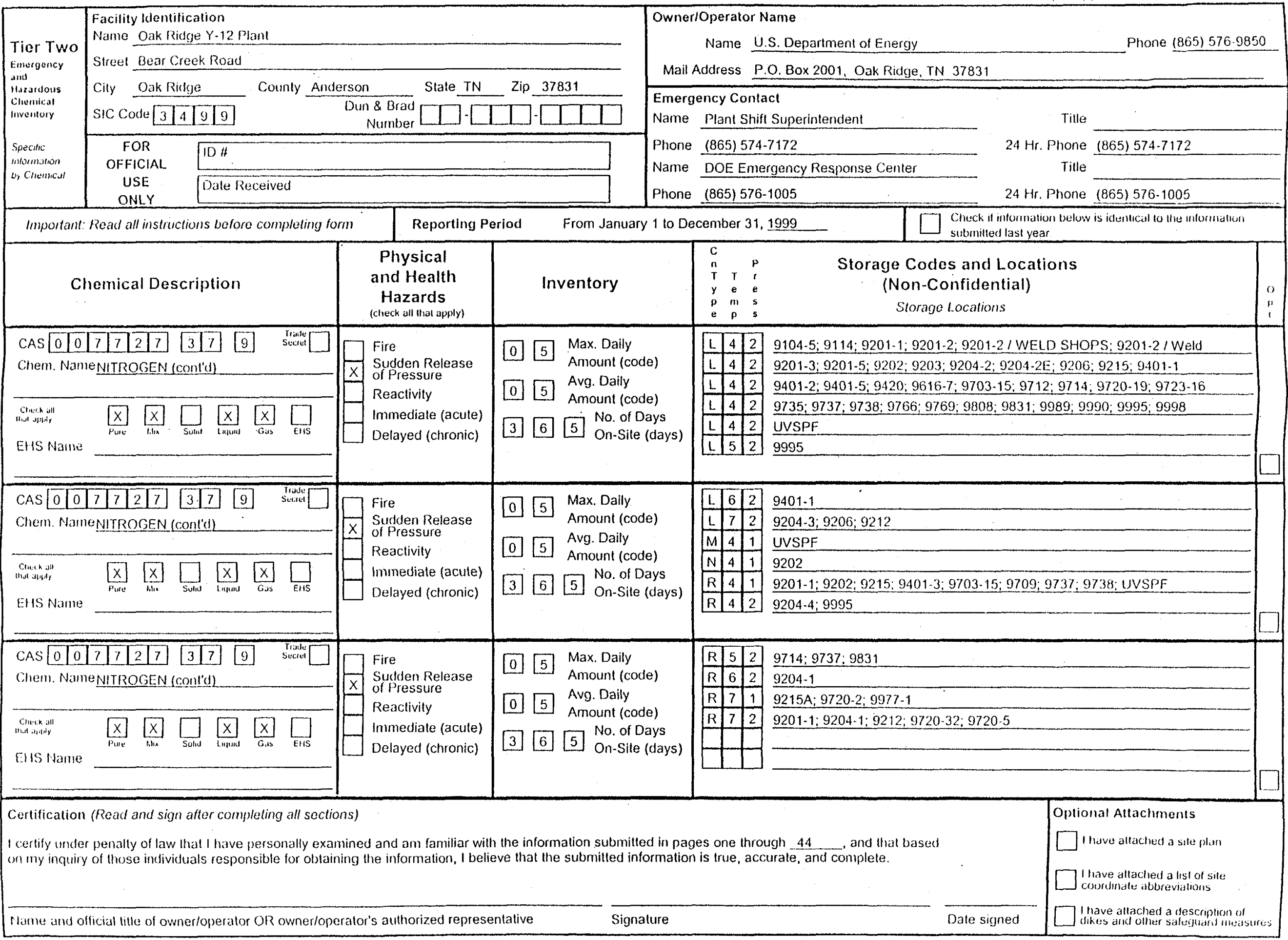




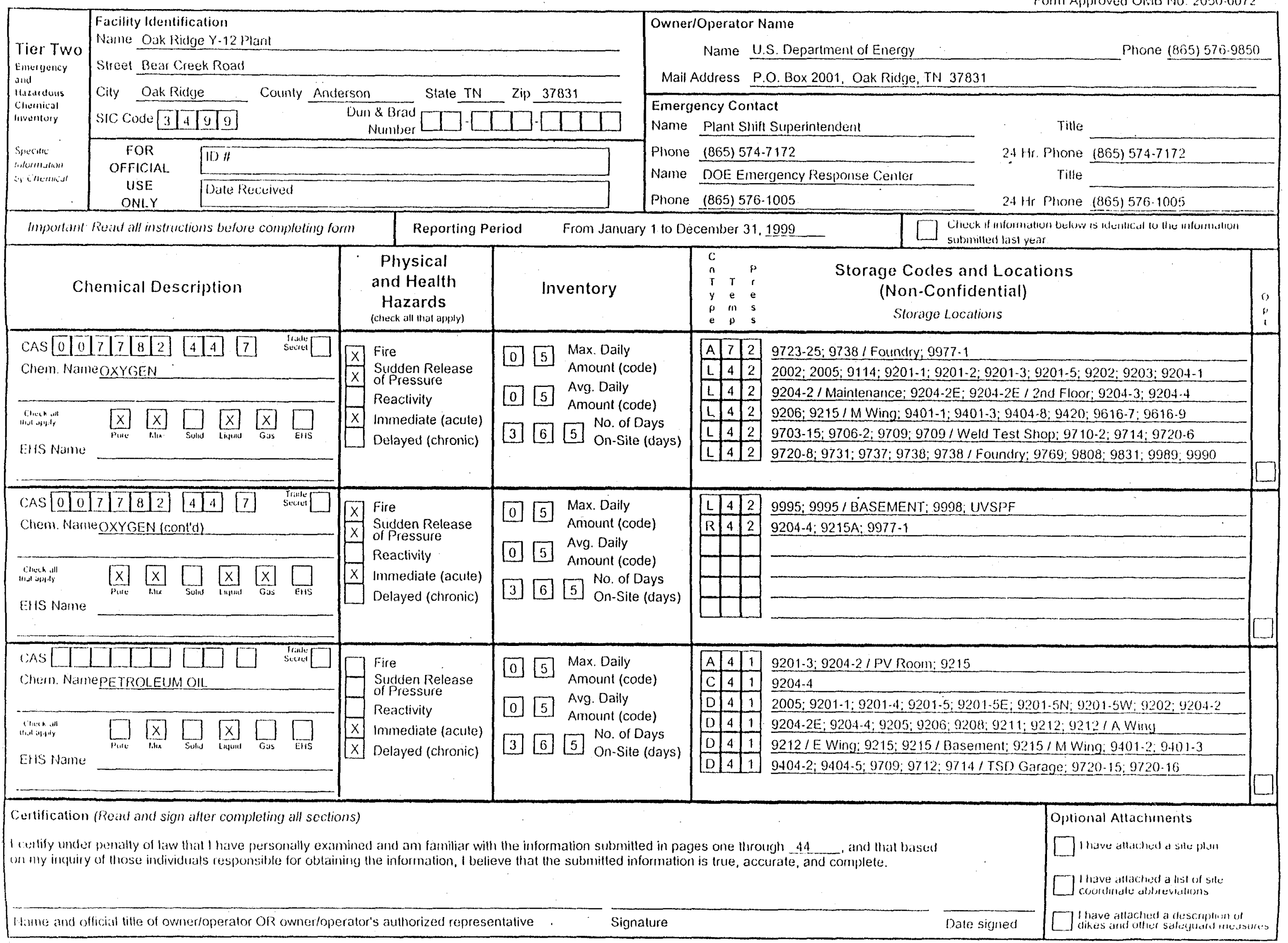




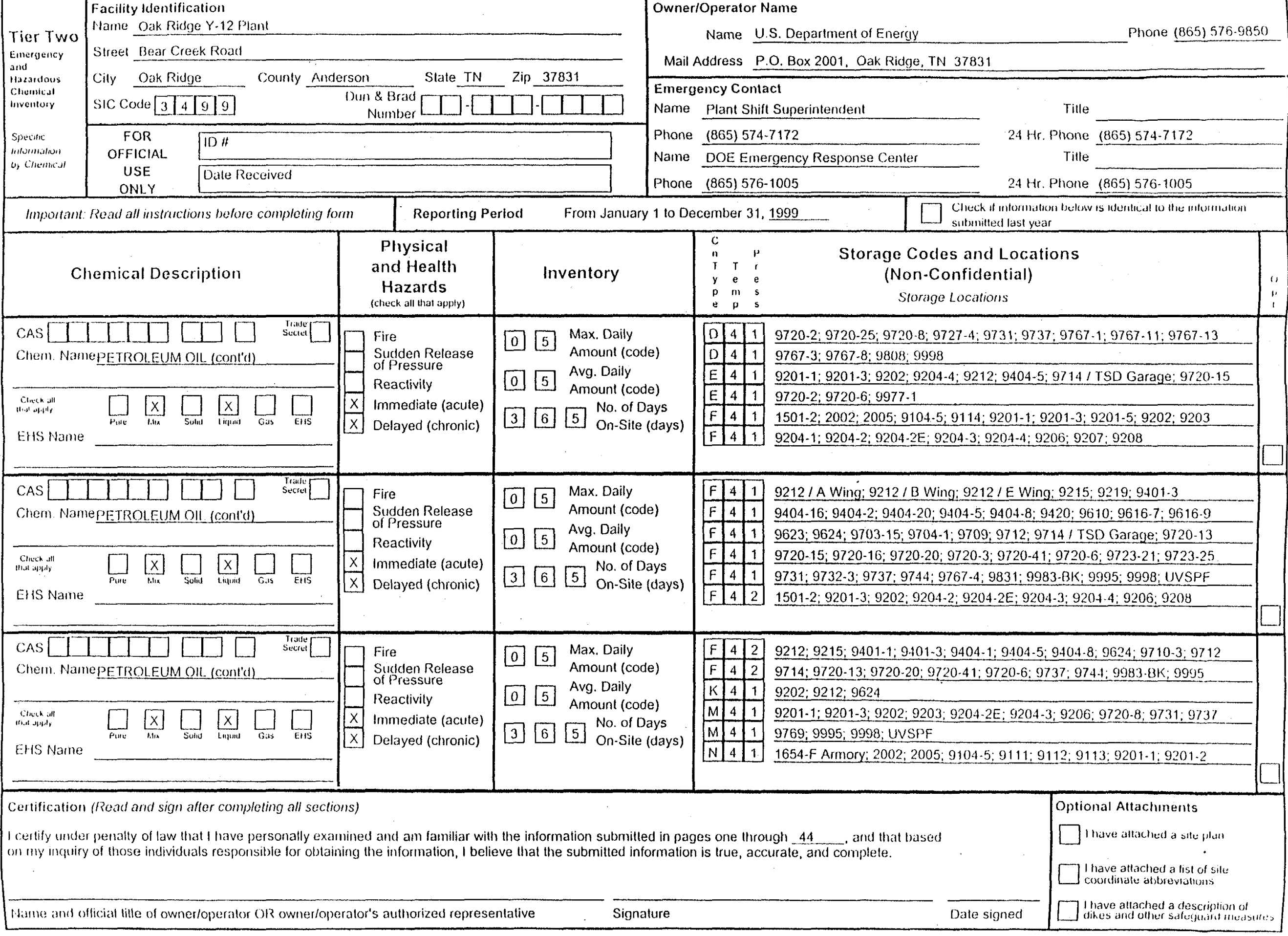




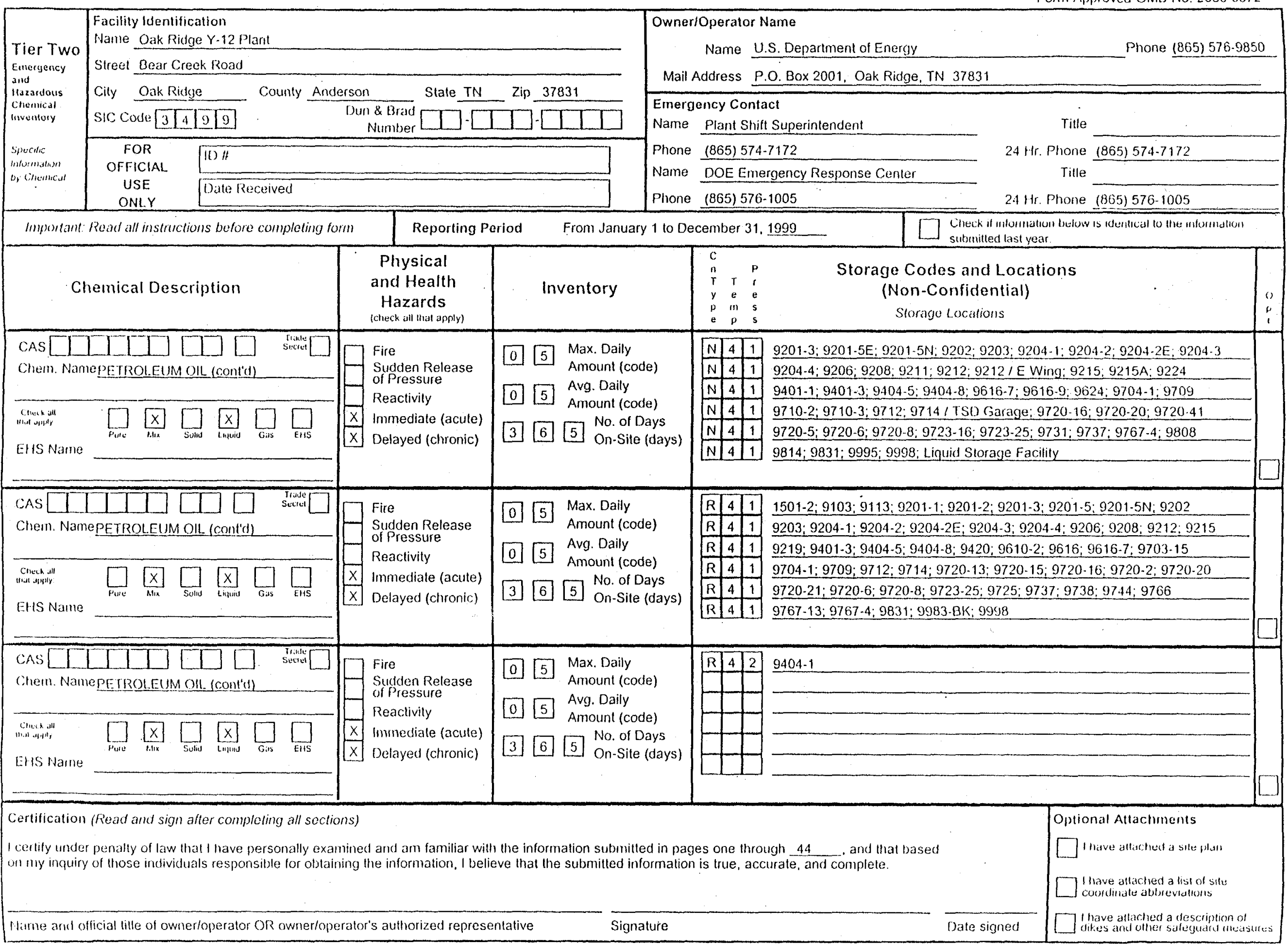




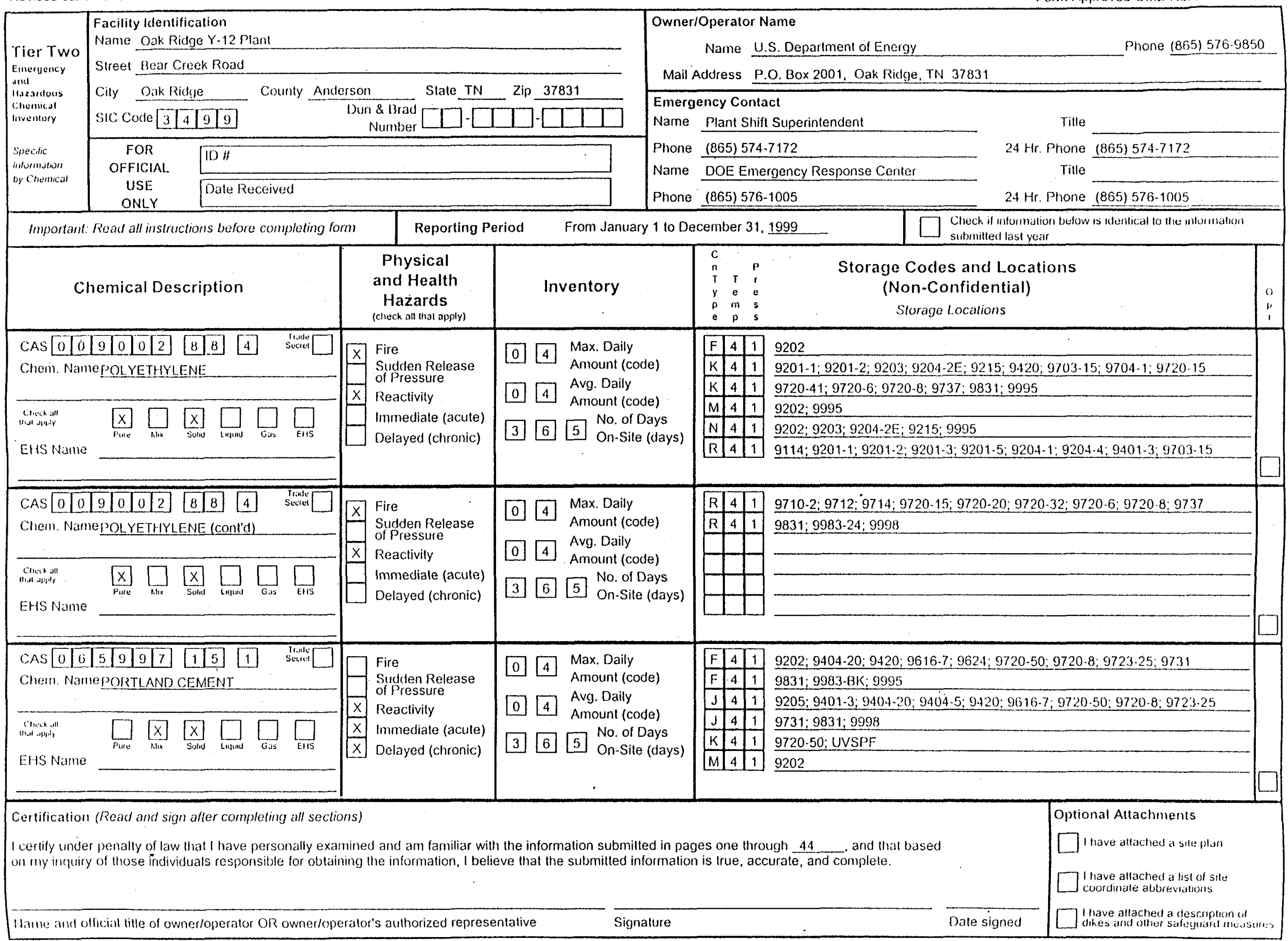




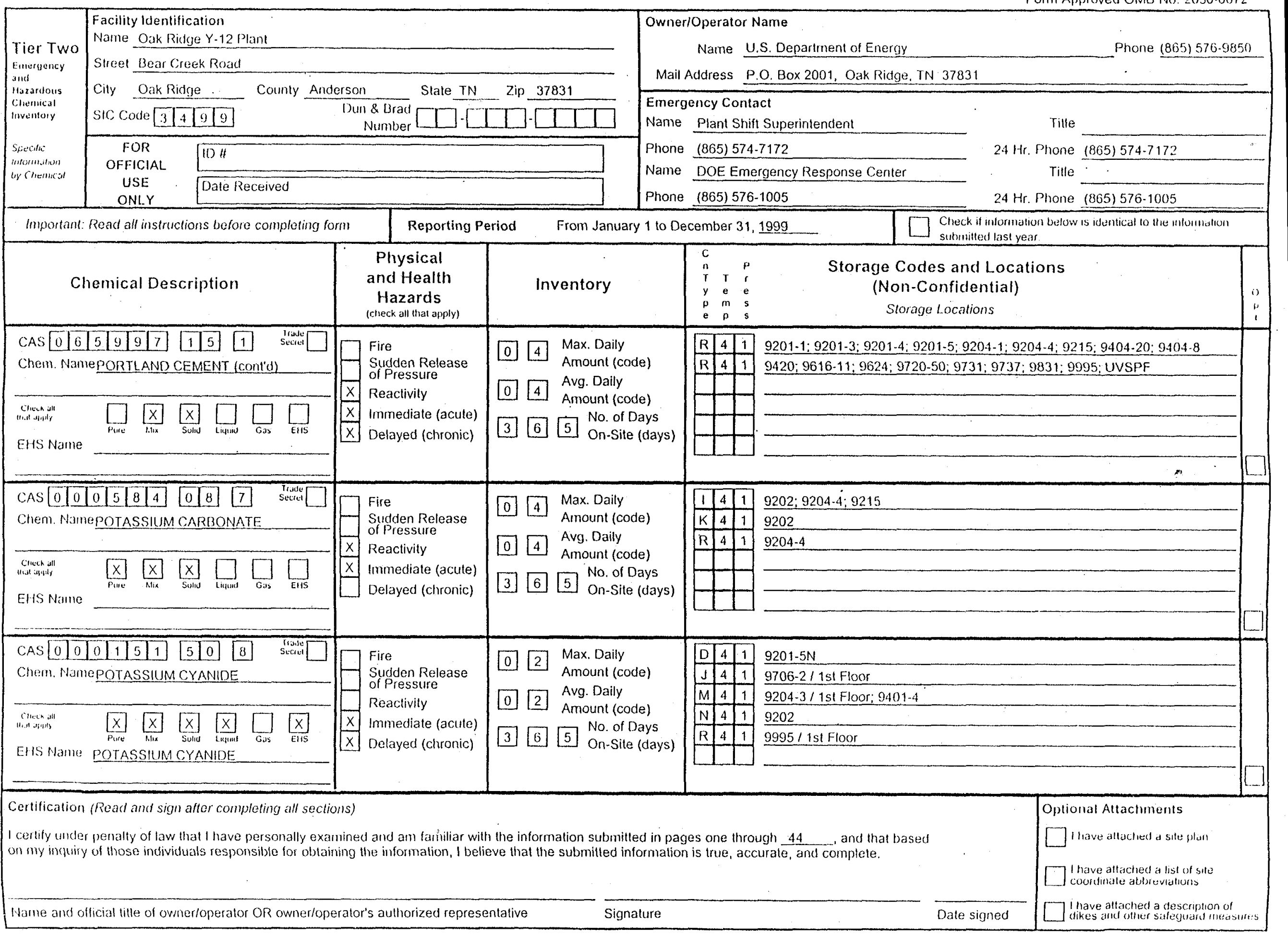




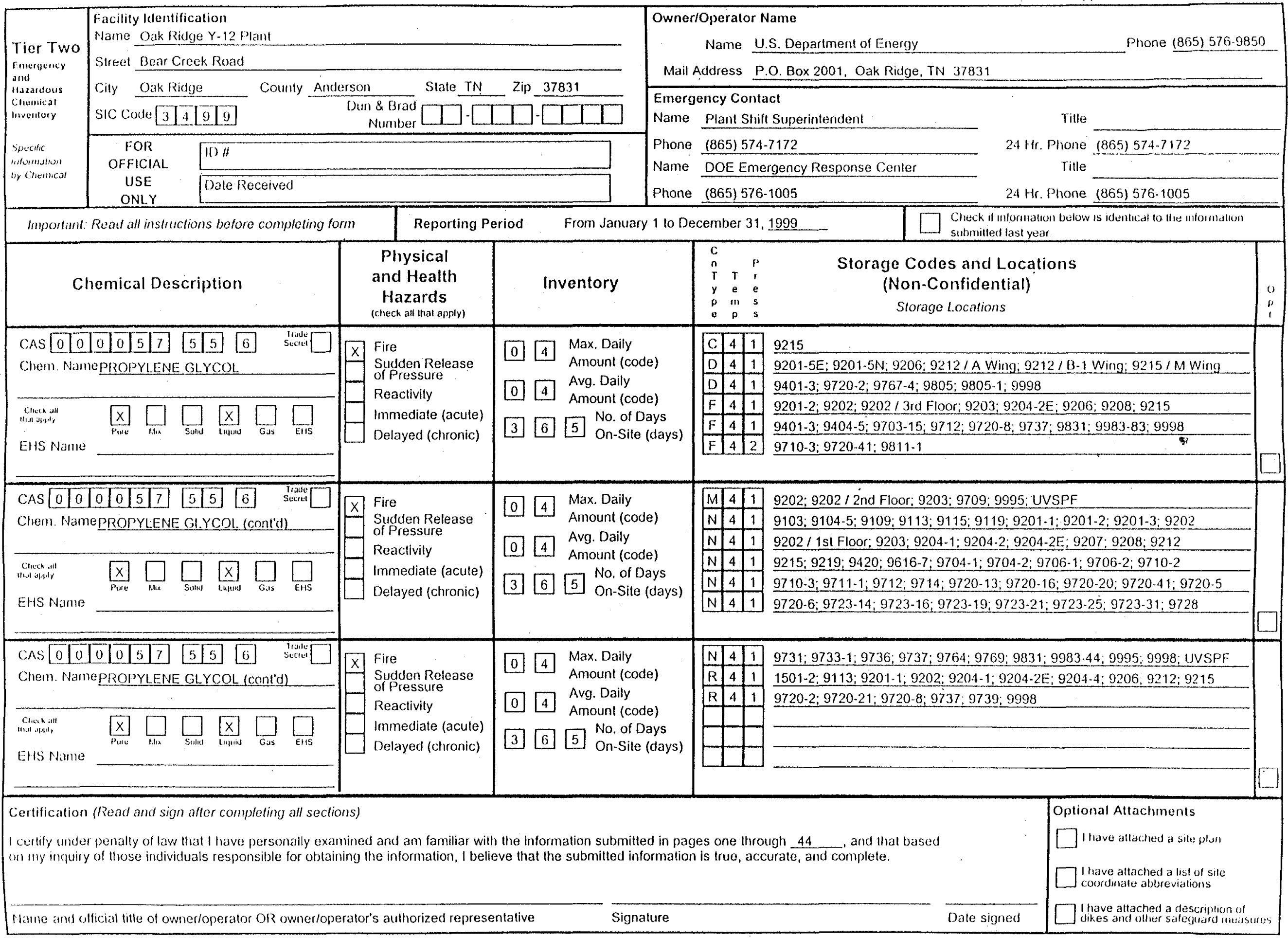




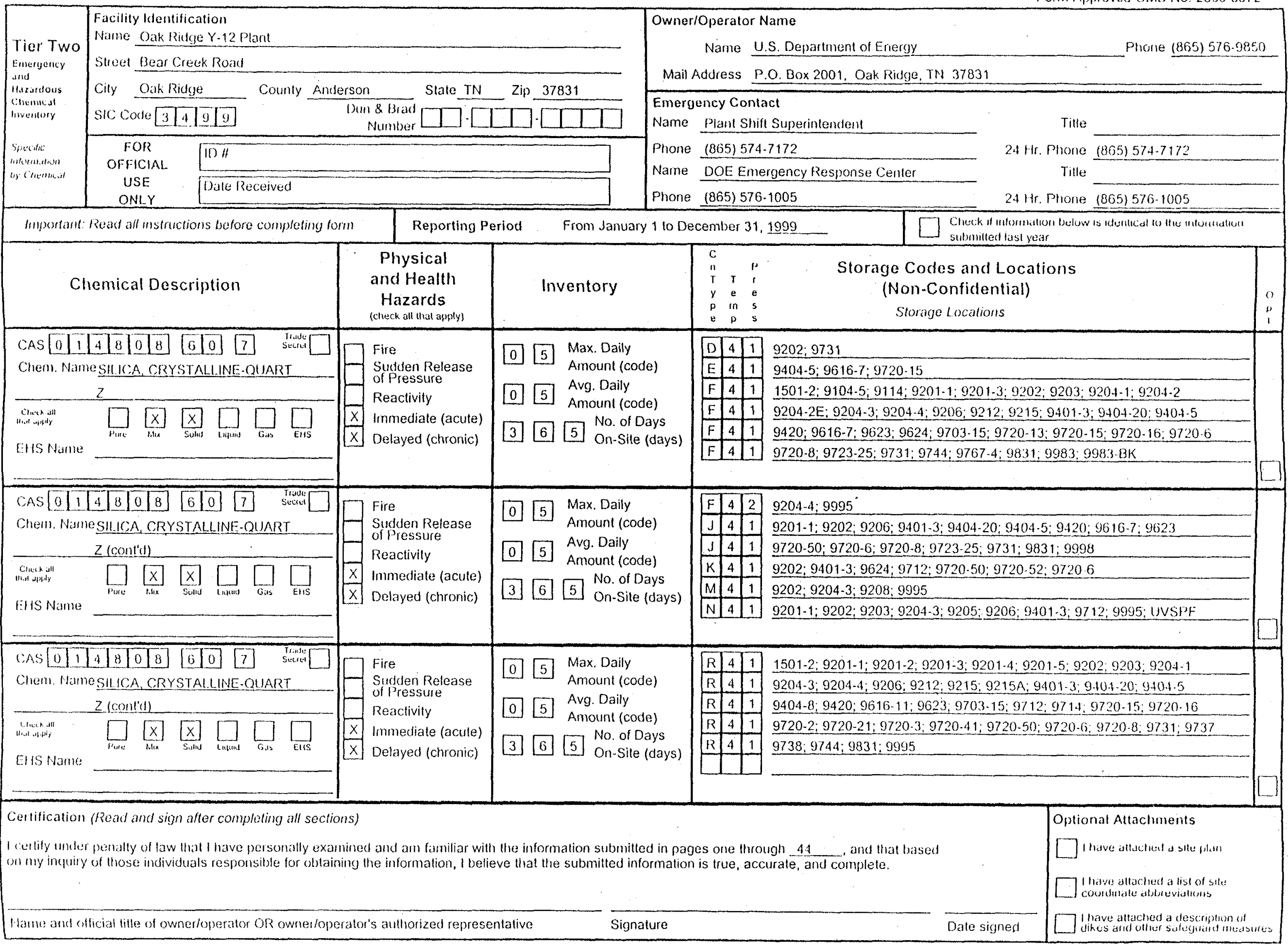




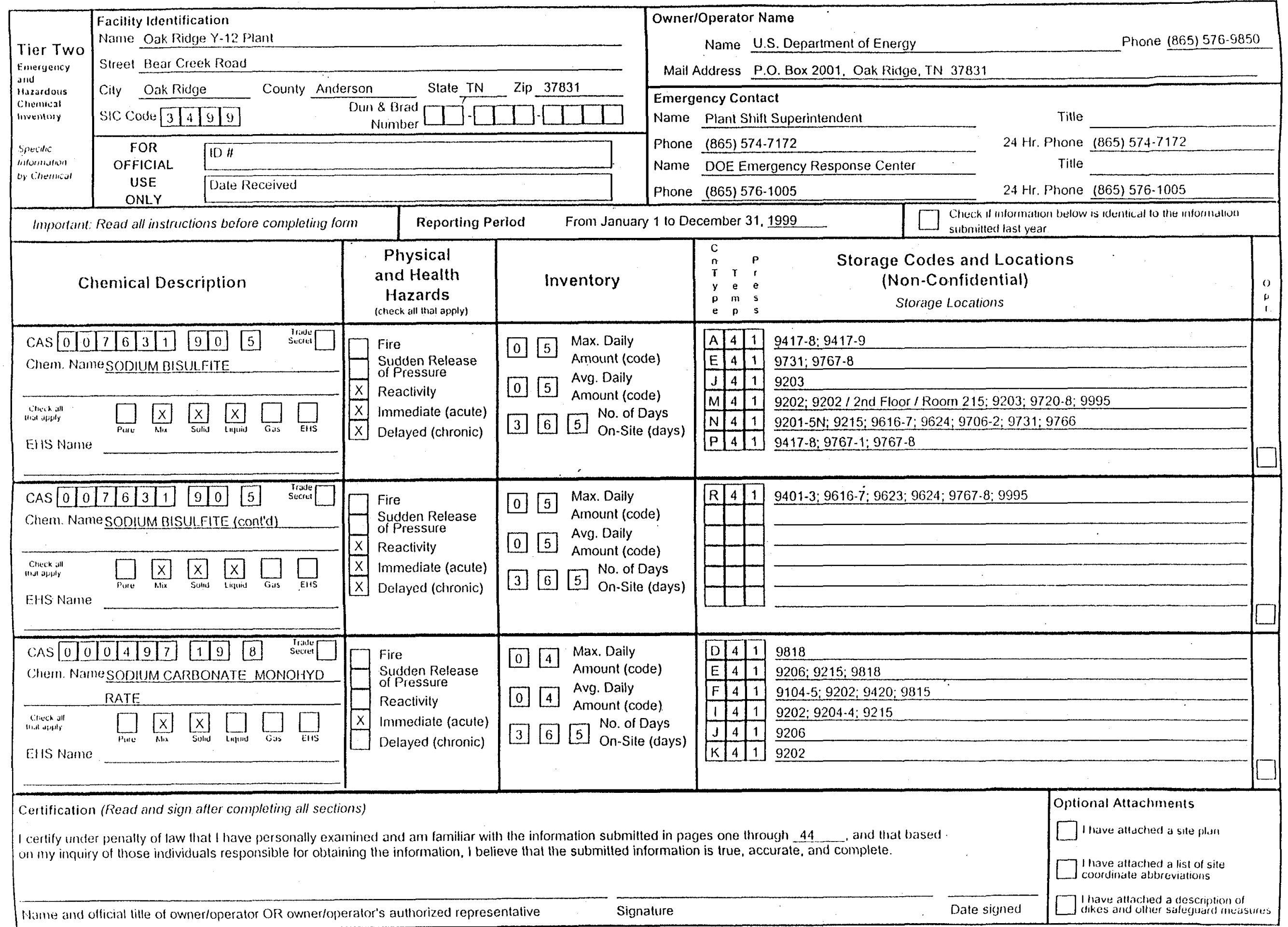




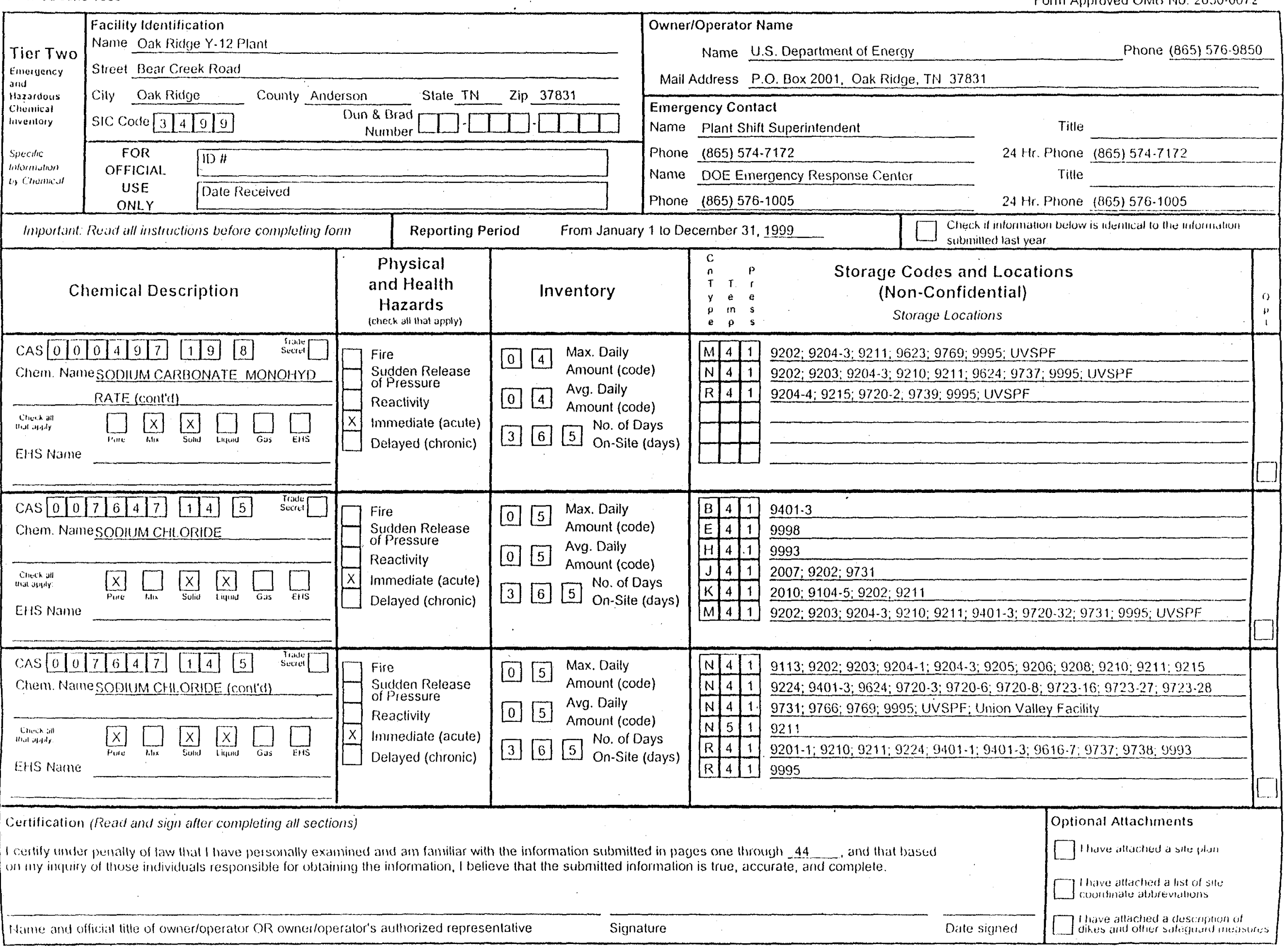




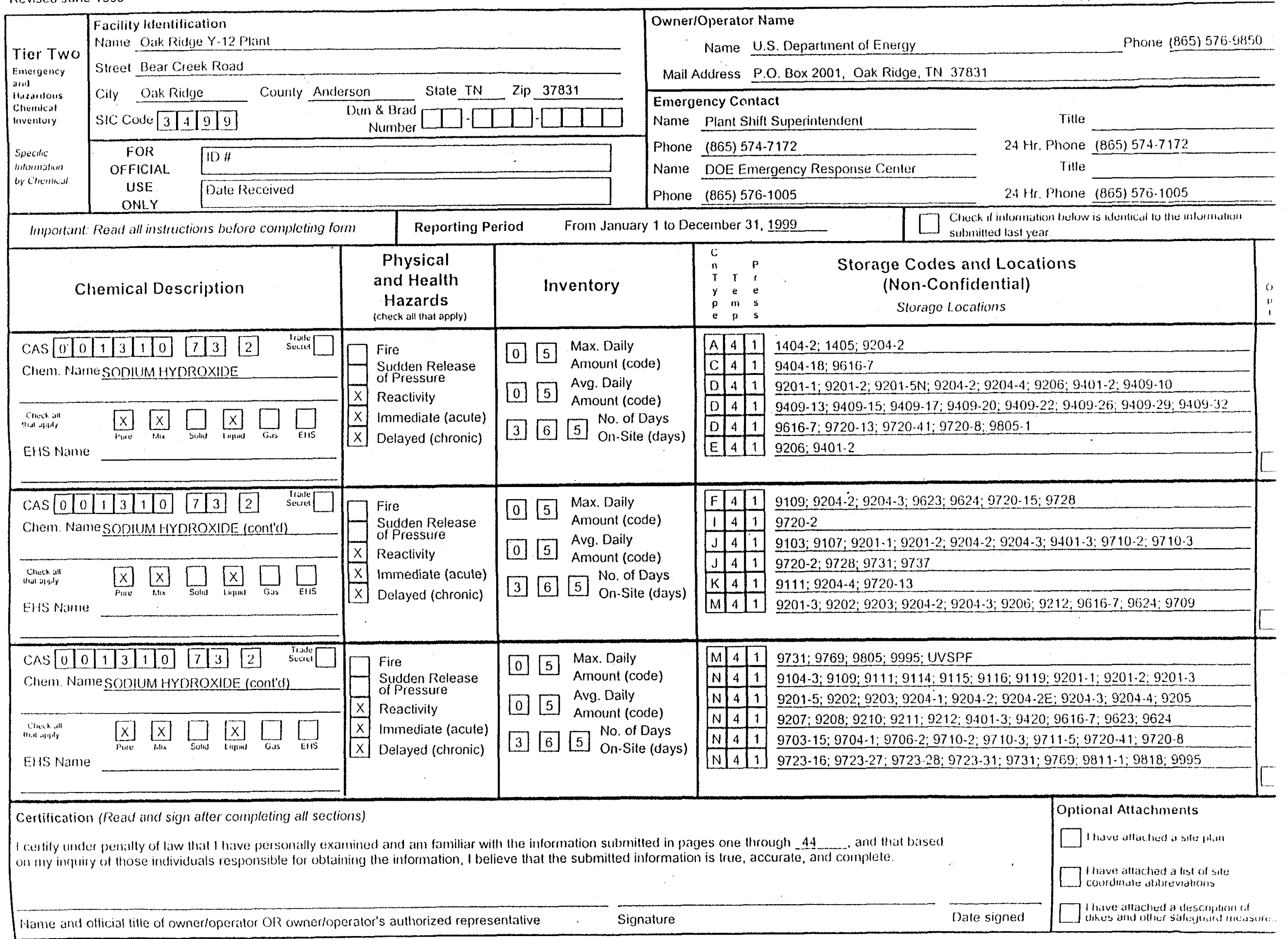




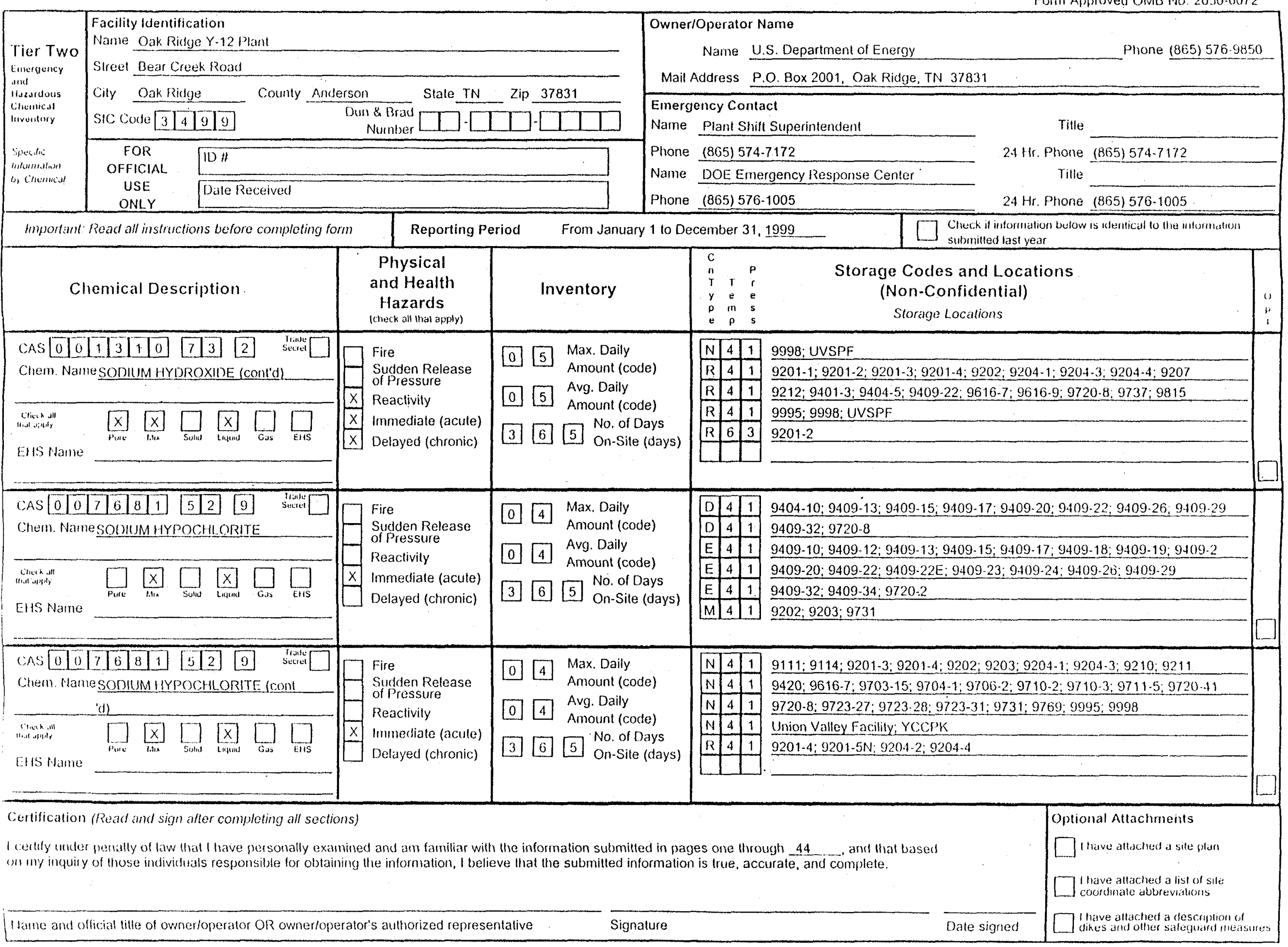




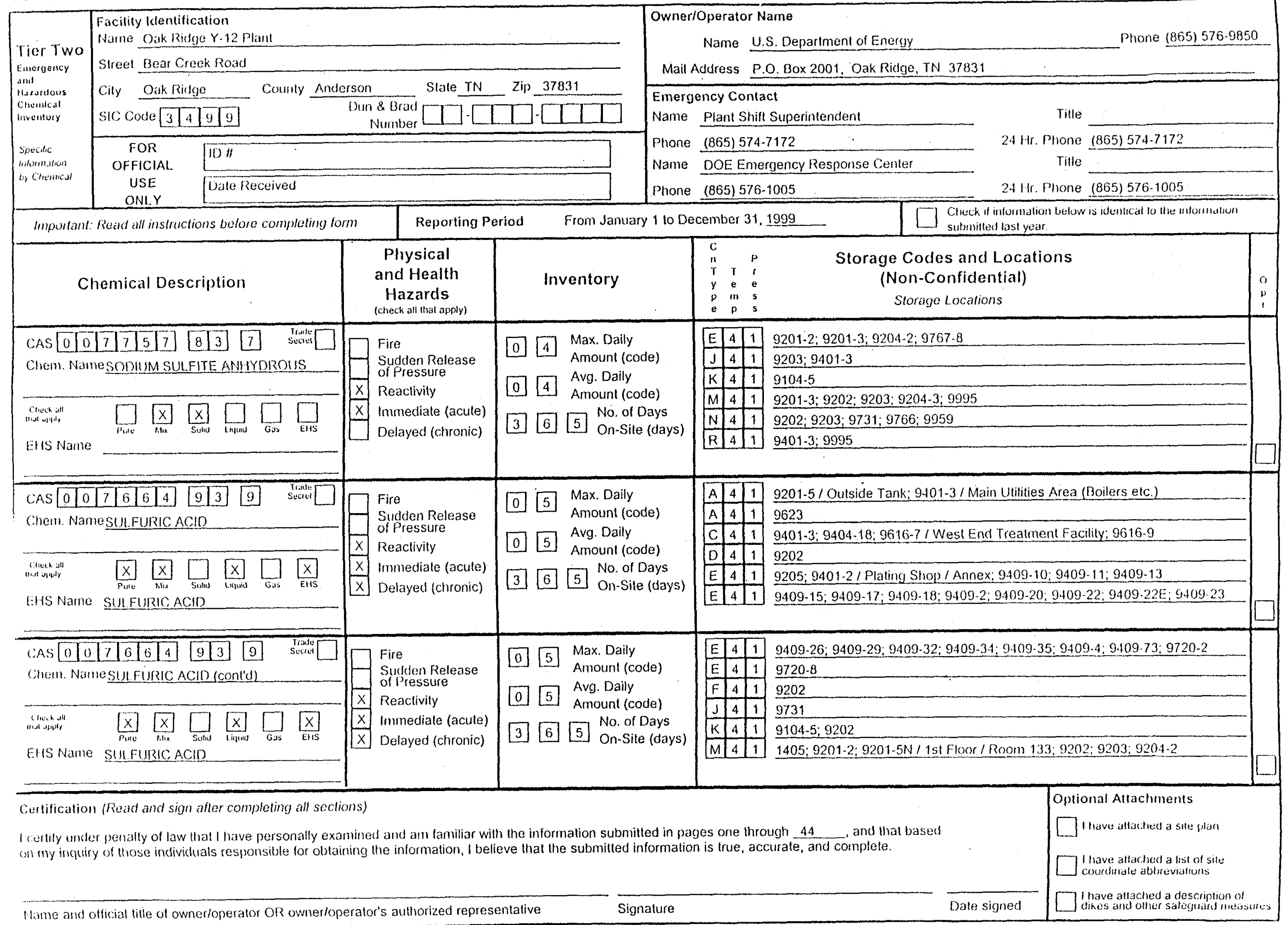




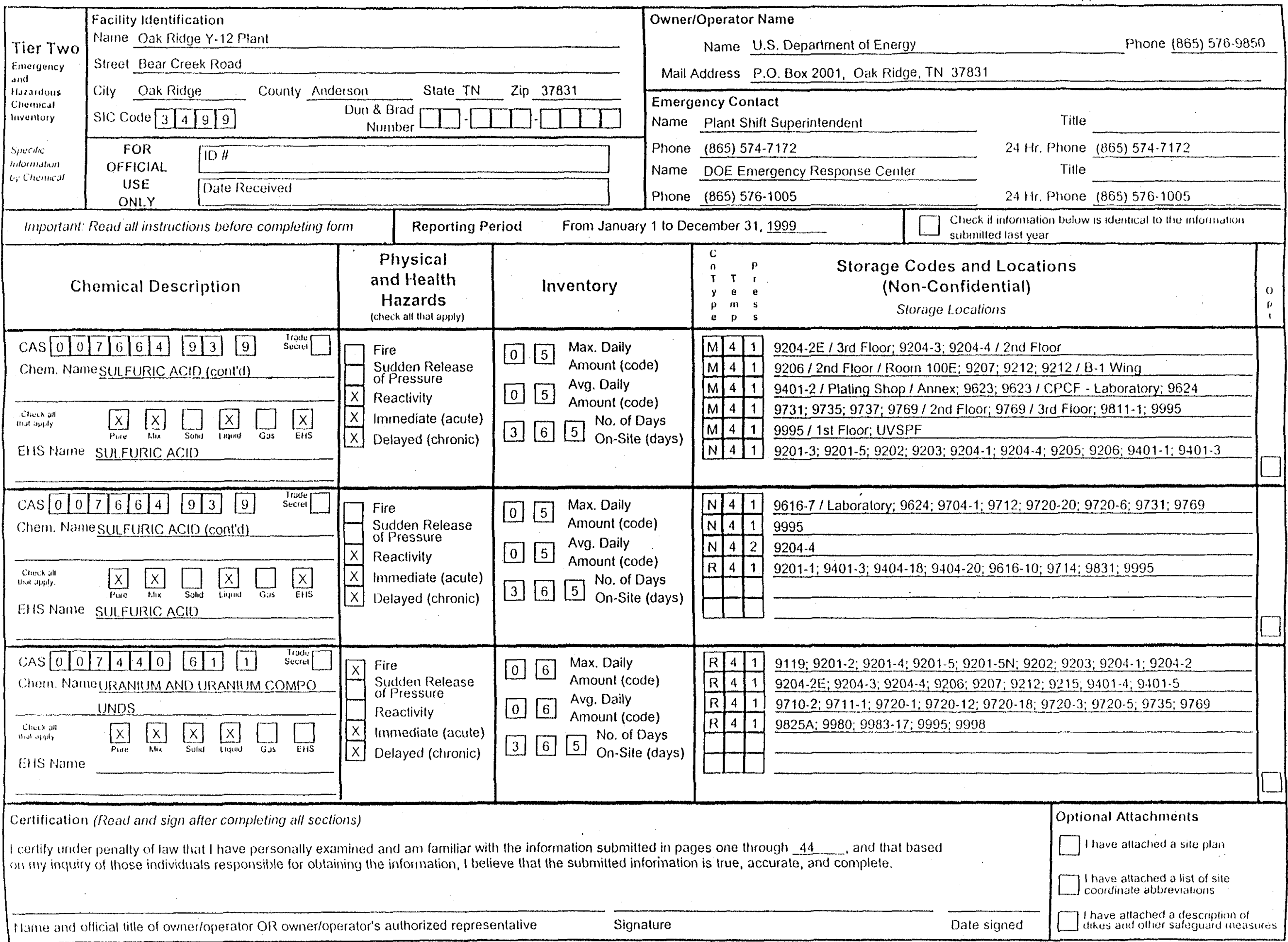




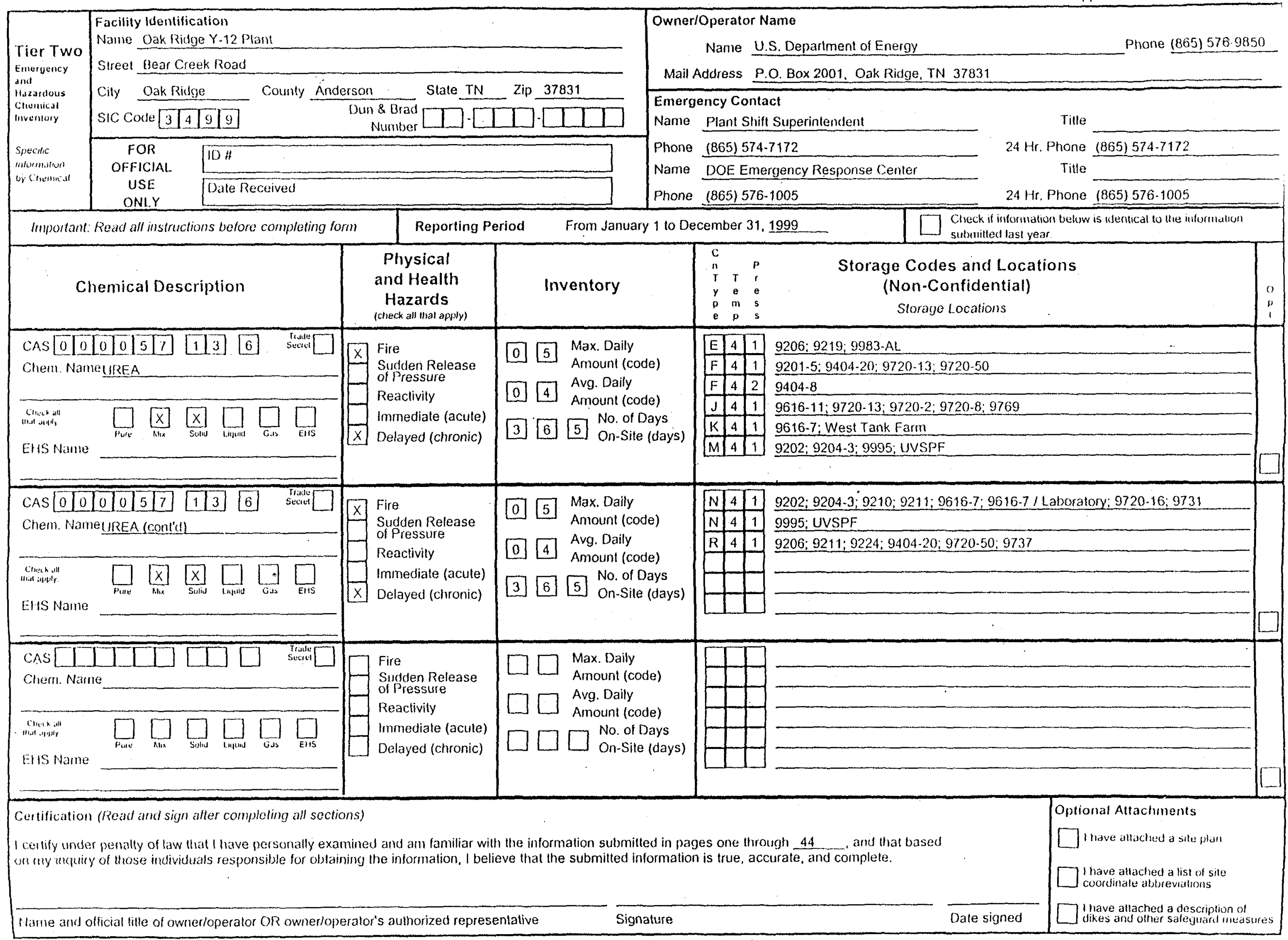


Distribution

H. F. Arnold, US West

S. Baloga, CDM Federal Program Corporation

J.D. Bolling

J. M. Eaton/R. A. Evans

R. T. Ford

C. M. Foster, MK-Ferguson

M. Gallahar, DOE-EOC

H. S. Hackler

C. C. Hill

E. Irwin

M. E. Lemmings, DOE-ORO

R. W. Martin, DOE-ORO

T. McWilliams/B. Starkey, East TN Mechanical

J. D. Rothrock/B. E. Cochran, DOE-ORO

R. R. Smith

Y-12 Records Services (1)/DOE-OSTI (2)

Y-12 Plant Shift Superintendent

EC Document Center-RC 